NBER WORKING PAPER SERIES

TAX CREDITS AND SMALL FIRM R\&D SPENDING

\author{
Ajay Agrawal \\ Carlos Rosell \\ Timothy S. Simcoe \\ Working Paper 20615 \\ http://www.nber.org/papers/w20615 \\ NATIONAL BUREAU OF ECONOMIC RESEARCH \\ 1050 Massachusetts Avenue \\ Cambridge, MA 02138 \\ October 2014, Revised May 2019
}

Previously circulated as "Do Tax Credits Affect R\&D Expenditures by Small Firms? Evidence from Canada." The Department of Finance, Canada generously provided data for this study. All views expressed herein are solely those of the authors and do not reflect the opinions or positions of the Department of Finance or the National Bureau of Economic Research. This research was funded by the Centre for Innovation and Entrepreneurship at the Rotman School of Management, University of Toronto and the Social Sciences and Humanities Research Council of Canada. We thank our colleagues at the University of Toronto, Boston University, and the Department of Finance, Canada for their advice and assistance. We also thank Iain Cockburn, Greg Leiserson, Jim Poterba, Nirupama Rao, Michael Salinger and two anonymous referees for their comments. Errors remain our own.

NBER working papers are circulated for discussion and comment purposes. They have not been peer-reviewed or been subject to the review by the NBER Board of Directors that accompanies official NBER publications.

(C) 2014 by Ajay Agrawal, Carlos Rosell, and Timothy S. Simcoe. All rights reserved. Short sections of text, not to exceed two paragraphs, may be quoted without explicit permission provided that full credit, including $(\odot$ notice, is given to the source. 
Tax Credits and Small Firm R\&D Spending

Ajay Agrawal, Carlos Rosell, and Timothy S. Simcoe

NBER Working Paper No. 20615

October 2014, Revised May 2019

JEL No. H2,H71,O25,O31,O38

\section{ABSTRACT}

In 2004, Canada changed the eligibility rules for its Scientific Research and Experimental Development (SRED) tax credit, which provides tax incentives for R\&D conducted by small private firms. Difference in difference estimates show a seventeen percent increase in total $R \& D$ among eligible firms. The impact was larger for firms that took the tax credits as refunds because they had no current tax liability. Contract $R \& D$ expenditures were more elastic than the $R \& D$ wage bill. The response was also greater for firms that invested in $R \& D$ capital before the policy change.

Ajay Agrawal

Rotman School of Management

University of Toronto

105 St. George Street

Toronto, ON M5S 3E6

CANADA

and NBER

ajay.agrawal@rotman.utoronto.ca

Carlos Rosell

Department of Finance, Canada

90 Elgin Street

Ottawa, ON K1P 0C6

Canada

carlos.rosell@canada.ca
Timothy S. Simcoe

Boston University

Questrom School of Business

595 Commonwealth Avenue

Boston, MA 02215

and NBER

tsimcoe@bu.edu 


\title{
Tax Credits and Small Firm R\&D Spending
}

\author{
By Ajay Agrawal and Carlos Rosell and Timothy Simcoe*
}

Draft: April 26, 2019

In 2004, Canada changed the eligibility rules for its Scientific Research and Experimental Development (SRED) tax credit, which provides tax incentives for $R \& D$ conducted by small private firms. Difference in difference estimates show a seventeen percent increase in total RED among eligible firms. The impact was larger for firms that took the tax credits as refunds because they had no current tax liability. Contract RED expenditures were more elastic than the R\&D wage bill. The response was also greater for firms that invested in RED capital before the policy change.

JEL: O38, H25, D83

Keywords: Research, Development, Tax Credits

Economists have long suspected that private incentives for research and development $(\mathrm{R} \& \mathrm{D})$ are too low, since knowledge spillovers cause research spending to resemble investment in a public good. Tax subsidies are a market-oriented approach to this problem. It is often unclear, however, whether fiscal incentives for R\&D produce a meaningful private response. This is particularly true for small firms that lack sophisticated tax-planning capabilities, have little or no tax liability, and might balk at the fixed costs of starting a new line of research. We

\footnotetext{
* Agrawal: University of Toronto and NBER, ajay.agrawal@rotman.utoronto.ca. Rosell: Department of Finance, Canada, carlos.rosell@fin.gc.ca. Simcoe: Boston University Questrom School of Business and NBER, tsimcoe@bu.edu. The Department of Finance, Canada generously provided data for this study. All views expressed herein are solely those of the authors and do not reflect the opinions or positions of the Department of Finance. This research was funded by the Centre for Innovation and Entrepreneurship at the Rotman School of Management, University of Toronto and the Social Sciences and Humanities Research Council of Canada. We thank our colleagues at the University of Toronto, Boston University, and the Department of Finance, Canada for their advice and assistance. We also thank Iain Cockburn, Greg Leiserson, Jim Poterba, Nirupama Rao, Michael Salinger and two anonymous referees for their comments. Errors remain our own. (c) 2018 by Ajay Agrawal, Tim Simcoe, and Carlos Rosell.
} 
use a change in eligibility rules for R\&D tax credits under Canada's Scientific Research and Experimental Development (SRED) tax incentive program to gain insight into the impact of fiscal incentives on $R \& D$ spending by small private firms. ${ }^{1}$

In 2004, Canadian-Controlled Private Corporations (CCPCs) with prior-year taxable income between $\$ 200$ and $\$ 500$ thousand became eligible for a fully refundable 35 percent $R \& D$ tax credit on a larger amount of qualifying $R \& D$ expenditures. We show that firms eligible to benefit from the more generous policy spent more on R\&D following the change, compared to firms with the same taxable income before the change. Specifically, eligible firms increased their R\&D spending by an average of 17 percent. Much of the response comes from firms with zero tax liability, who would not benefit from a non-refundable credit, but can convert (some) refundable SRED credits to cash. We examine the components of $R \& D$ spending, and find a smaller effect for $R \& D$ wages than for contract R\&D expenditures. Finally, we show that firms increase their R\&D spending by a larger amount if they recently made $\mathrm{R} \& \mathrm{D}$ related capital expenditures.

Our findings make three contributions to the literature on $R \& D$ tax incentives. First, we focus on small private firms: the average firm in our estimation sample has annual revenues of $\$ 1.2$ million. While large firms account for the bulk of private R\&D spending, several authors have argued that small firms have a comparative advantage in product innovation or exploratory research (Cohen and Klepper, 1996; Akcigit and Kerr, 2010). Our estimates suggest that small private firms are quite responsive to $R \& D$ tax incentives, consistent with the findings of other recent studies (Dechezleprêtre et al., 2016).

Second, because SRED credits are fully refundable for most of the firms in our sample, our findings are relevant to debates over the design of the U.S. R\&D tax credit. Before 2016, the U.S. federal R\&D tax credit was non-refundable, so small

\footnotetext{
${ }^{1}$ While the program is commonly referred to as SR\&ED in Canada, we conserve ampersands by adopting the acronym SRED throughout this paper.
} 
firms that did not owe taxes could only benefit from carry-forwards. The law was changed in December 2015, allowing firms with gross receipts less than $\$ 5$ million to deduct up to $\$ 250,000$ of qualifying R\&D expenditures from their payroll tax, making the R\&D tax credit essentially refundable for small firms. ${ }^{2}$ Roughly half of the firm-year observations in our data have no tax liability. We show that zerotax-liability firms are more responsive to the expansion of the refundable credit, presumably because these firms face a larger increase in the after-tax marginal cost of R\&D once all of their credits are consumed.

Finally, our results highlight the potential importance of fixed costs in small firms' response to $R \& D$ tax incentives. We provide two pieces of evidence on this point. First, we show that contract R\&D spending (a spending category we assume to have relatively low fixed costs) has a greater after-tax cost elasticity than the R\&D wage bill. Second, we show that firms with recent R\&D-related capital expenditures (one source of fixed costs) are more responsive to the more generous tax incentives.

In the remainder of the paper, we review prior research on R\&D tax credits, describe the Canadian SRED program change and our empirical strategy in greater detail, present our empirical results, and speculate on the implications of our findings.

\section{Related Literature}

Hall and Van Reenen (2000) review the early literature on R\&D tax incentives and identify two broad empirical strategies. One approach is to estimate a reduced form R\&D demand equation that includes a shift parameter to measure the impact of changes in the R\&D tax credit. This strategy is used in several papers, including Swenson (1992), Bailey and Lawrence (1992), and Czarnitzki et al. (2011). A second approach is to regress R\&D spending on the after-tax user cost

\footnotetext{
${ }^{2}$ The new law also made the U.S. R\&D tax credit permanent. Observers such as Tyson and Linden (2012) had long called for both changes.
} 
of $R \& D$ to obtain a scale-free estimate of the cost elasticity of R\&D spending. ${ }^{3}$ This latter method is implemented by Hall (1993), Bloom et al. (2002), Lokshin and Mohnen (2012), Wilson (2009), and Rao (2016). Given the complexities of calculating the R\&D user-cost, and the endogeneity introduced when user-cost is function of $R \& D$ spending, the reduced-form approach is often simpler. We estimate a reduced form expenditure function and use the design of the credit to calculate an implied user-cost elasticity of R\&D.

While early research on the impact of $R \& D$ tax incentives focused on the United States, some recent studies provide evidence from other countries, including Canada (Dagenais et al., 1997; Baghana and Mohnen, 2009; Czarnitzki et al., 2011), Japan (Yohei, 2011; Koga, 2003), the Netherlands (Lokshin and Mohnen, 2012), the United Kingdom (Dechezleprêtre et al., 2016; Guceri and Liu, 2015) and China (Chen et al., 2017). The results of these studies are broadly consistent with those surveyed in Becker (2015), and with the conclusion in Hall and Van Reenen (2000) that, "A tax price elasticity of around unity is still a good ballpark figure, although there is a good deal of variation around this from different studies as one would expect."

Our study is one of a small number of papers on $R \& D$ tax credits to focus on small firms. Lokshin and Mohnen (2012) split their sample into large and small firms (above or below 200 employees) and find that small firms have a larger cost elasticity of R\&D. Koga (2003) finds the opposite result - a larger cost elasticity for large firms — in a sample of Japanese manufacturing firms, though in that study size is based on capital rather than employees. More recently Dechezleprêtre et al. (2016) estimate a user cost elasticity of -2.6 for firms with assets in the vicinity of $86 \mathrm{M}$ Euros, the threshold for "small or medium" under a UK administrative rule. We do not provide an explicit comparison of the impact of tax credits on large and small firms, since our natural experiment only impacts

\footnotetext{
${ }^{3}$ To our knowledge, the only papers to examine innovation-related outcome variables other than R\&D spending are Czarnitzki et al. (2011) and Dechezleprêtre et al. (2016).
} 
those with taxable income between $\$ 200$ and $\$ 500$ thousand. Nevertheless, our estimates do suggest that the very small firms in our sample have a user-cost elasticity greater than one.

To our knowledge, no study has sought direct evidence of fixed costs in R\&D investment. Many authors have noted that the within-firm variance in R\&D expenditures is much lower than for capital goods and that one way to rationalize this observation is to assume some type of adjustment cost. There is some disagreement, however, over what these costs might be. For example, Lach and Schankerman (1989) argue that the bulk of $R \& D$ spending are labor costs, which should not impose substantial fixed costs, at least for large firms. On the other hand, Hall (1993) suggests that the long-term nature of research and the fact that much of a firm's knowledge capital is tied up in its R\&D workforce make it difficult for even large firms to quickly adjust their R\&D spending. A number of papers seek evidence of adjustment costs in the lag structure of R\&D investments (e.g., Bloom et al., 2002). This is a difficult empirical exercise though, precisely because within-firm R\&D expenditures are typically quite smooth over time (e.g., Hall et al., 1986). Unlike prior studies that identify adjustment costs by using a dynamic model (Hall, 1993; Bernstein and Nadiri, 1988), we compare different types of R\&D spending - contracts versus wages - and utilize direct proxies for the firm-level cost of adding $R \& D$ resources.

Finally, as noted in the introduction, the refundable nature of SRED credits makes our results relevant to recent U.S. tax policy changes. Because most firms in our sample earn fully refundable credits, we cannot test whether the elasticity of $\mathrm{R} \& \mathrm{D}$ differs for credits earned as non-cash carry-forwards versus cash equivalents. We do observe, however, that zero-tax-liability firms are more responsive to the expansion of the refundable credit program. This finding complements the results in Zwick and Mahon (2014), which show that small financially constrained firms exhibit a greater response to accelerated depreciation benefits in their capital expenditures, and those of Himmelberg and Petersen (1994), which show that 
$R \& D$ investments are sensitive to cash flow for small firms in high-tech industries.

\section{SRED Policy and Empirical Framework}

\section{A. The SRED Tax Incentive Program}

The SRED program is a tax incentive provided by the federal government to encourage businesses of all sizes and sectors to conduct research and development in Canada. To qualify for SRED support, a firm's R\&D expenditures must broadly satisfy two conditions. First, the work must be a "systematic investigation or search that is carried out in a field of science or technology by means of experiment or analysis." And second, this work must be undertaken to achieve a technological advancement or further scientific knowledge. ${ }^{4}$

SRED has three main features. First, all companies operating and carrying out R\&D in Canada may deduct 100 percent of qualifying R\&D expenditures (including capital expenditures) from their taxable income. ${ }^{5}$ Second, SRED provides a two-tier tax credit. All firms are eligible to receive an investment tax credit on qualifying expenditures at the general rate of 20 percent. ${ }^{6}$ Small and mediumsized CCPCs can receive an additional 15 percent tax credit, for a total credit rate of 35 percent, on $\mathrm{R} \& \mathrm{D}$ expenditures up to a threshold called the expenditure limit. Third, some SRED credits are refundable. Specifically, credits earned at the 35 percent rate are fully refundable, while credits earned at the 20 percent rate are non-refundable (but can be used to offset future tax liability).

Our empirical strategy exploits a change in the expenditure limit, which is a function of prior-year taxable income and prior-year taxable capital employed in Canada. (To simplify exposition, we focus only on how taxable income affects the expenditure limit, because taxable capital is only relevant for a handful of the

\footnotetext{
${ }^{4}$ See $\quad$ http://www.cra-arc.gc.ca/txcrdt/sred-rsde/clmng/lgbltywrkfrsrdnvstmnttxcrdtseng.html\#N101D1 for more detail.

${ }^{5}$ Until 2014, qualifying expenditures included both current and capital expenditures used in the conduct of qualifying SRED activities. Since January 1, 2014, capital expenditures no longer qualify.

${ }^{6}$ As of January 1, 2014, the general credit rate is now 15 percent.
} 
firms in our estimation sample.) Before 2004, the expenditure limit was $\$ 2$ million for CCPCs with prior-year taxable income below $\$ 200$ thousand, with a phase-out for firms earning between $\$ 200$ and $\$ 400$ thousand. In 2004, as part of a broad package of tax reforms, the lower bound of the phase-out range was increased by $\$ 100$ thousand. This change in the expenditure limit formula was announced on February 18, 2003, and our inquiries with the Department of Finance of the Government of Canada suggest that it is very unlikely any firms knew about the plan before that date.

To illustrate the effects of expenditure limit reformulation, let $T Y_{i(t-1)}$ denote prior-year taxable income, and define a variable $Z_{t}$ that governs the location of the phase-out range. The expenditure limit for firm $i$ in year $t\left(E L_{i t}\right)$ can then be written as

$$
E L_{i t}=\min \left\{\$ 2 \text { million, } \max \left\{0, Z_{t}-10 T Y_{i(t-1)}\right\}\right\}
$$

Figure 1 graphs this function before and after the 2004 policy-change. The solid line represents the pre-2004 expenditure limit, based on $Z_{t}=\$ 4$ million. R\&D expenditures below this line earned refundable tax credits at the rate of 35 percent, while additional expenditures above this threshold earned non-refundable credits at 20 per cent. The 2004 SRED policy-change increased $Z_{t}$ to $\$ 5$ million, shifting rightward the expenditure limit phase-out region, represented by the dashed line in Figure 1. If a firm's lagged taxable income was between $\$ 200$ and $\$ 500$ thousand, and if their R\&D investment crossed the pre-2004 expenditure limit, then the policy change reduced their after-tax cost of R\&D. More precisely, the marginal after-tax cost of $\mathrm{R} \& \mathrm{D}$ declined for firms located in the darkly shaded parallelogram, while the average after-tax cost of $R \& D$ declined for firms with total R\&D spending in the lightly shaded area above the parallelogram. Note that Figure 1 is not drawn to scale: in practice the expenditure limit phase-out is much steeper, with each $\$ 1$ increase in lagged taxable income producing a $\$ 10$ 
drop in the amount of $\mathrm{R} \& \mathrm{D}$ eligible for the refundable $35 \%$ credit rate.

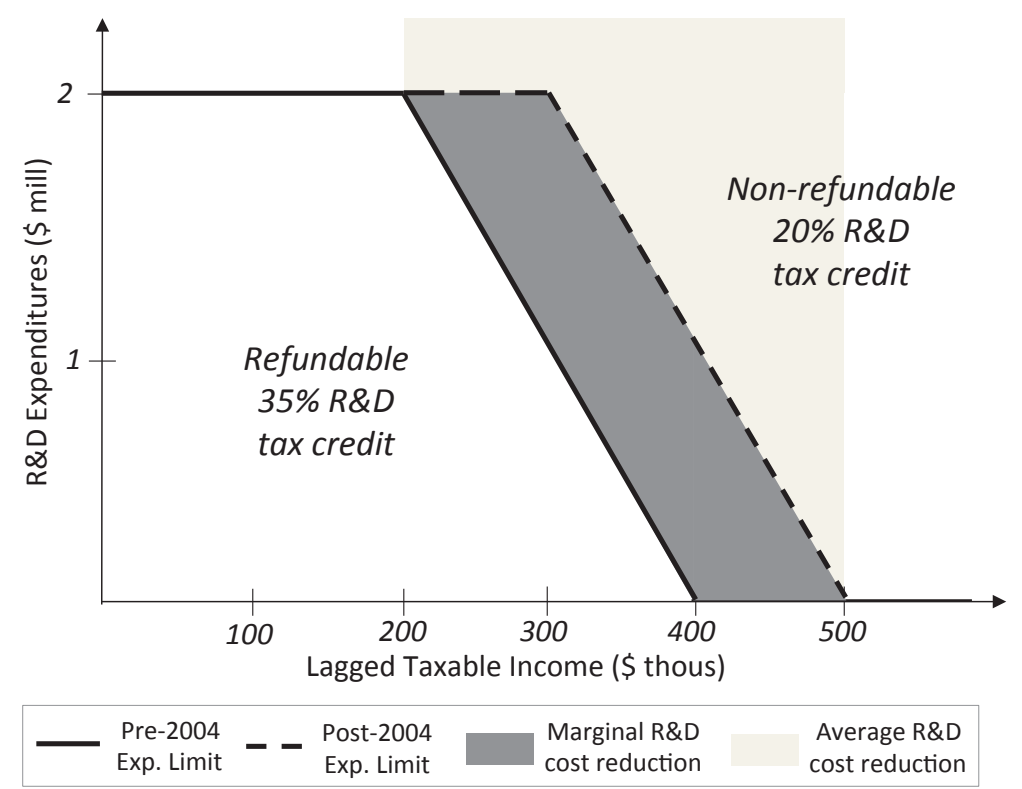

Figure 1. SRed Expenditure Limits Before and After Program Change

Because the marginal cost of $R \& D$ increases dis-continuously at the expenditure limit, we should expect some bunching of firms near that point, and Appendix A shows that bunching does occur. ${ }^{7}$ It is therefore important to recognize that our identification strategy does not rely on variation in tax rates produced by firms actually crossing the threshold. Instead, we exploit variation in the after-tax cost of $R \& D$ produced by the expenditure limit reformulation illustrated in Figure 1.

In addition to the expenditure limit, a firm's marginal credit rate depends on its tax liability. As noted above, SRED credits earned at the 35 percent rate are fully refundable. ${ }^{8}$ Credits earned at the 20 percent rate reduce the marginal cost

\footnotetext{
${ }^{7}$ The appendix also provides a simple model to explain how declining marginal returns to R\&D can produce a discontinuous increase in the number of observations just above the discontinuity, which is what we actually find.

${ }^{8}$ Here we assume that the marginal SRED dollar represents a current (as opposed to a capital) expenditure. This is an important and sensible assumption. It is important because current expenditures earning the 35 percent credit rate are fully refundable, while only 40 percent of credits earned from capital expenditures are refundable. It is sensible to assume the additional dollar invested is a current expenditure because the vast majority of CCPC SRED expenditures are current expenditures.
} 
of R\&D by 20 cents as long as the firm has a remaining tax liability, since these credits can be used to fully offset taxes payable. If a firm does not owe taxes, but does have the maximum expenditure limit ( $\$ 2$ million during our sample period), it earns a fully refundable tax credit of 8 percent. ${ }^{9}$ Thus, letting $R$ denote R\&D expenditures and Tax the total taxes owed after accounting for all other credits and deductions, a firm's marginal credit rate is

$$
\rho(R, E L, \operatorname{Tax})= \begin{cases}0.35 & \text { if } R \leq E L \\ 0.20 & \text { if } E L<R \text { and } 0<\operatorname{Tax} \\ 0.08 & \text { if } E L<R, \text { Tax } \leq 0 \text { and } E L=\$ 2,000,000 \\ 0.00 & \text { if } E L<R, \text { Tax } \leq 0 \text { and } E L<\$ 2,000,000\end{cases}
$$

This formula for the marginal credit rate shows that crossing the expenditure limit leads to a smaller increase in the after-tax cost of $R \& D$ for firms with tax liability, because the cash value of their credits will decline by 15 cents per dollar of $\mathrm{R} \& \mathrm{D}$ expenditure, as opposed to the 27 or 35 cent drop experienced by a firm with zero tax liability.

\section{B. Empirical Framework}

Our empirical analysis is based on an R\&D demand equation similar to (3.1) in Hall and Van Reenen (2000), where we exploit the reformulation of the expenditure limit for identification. Specifically, we estimate the following reduced-form model of R\&D spending:

$$
E\left[R_{i t} \mid T_{i t}, X_{i t}\right]=\exp \left\{T_{i t} \text { PostPolicy } \beta_{1}+T_{i t} \beta_{2}+\gamma_{i}+\lambda_{j t}+X_{i t} \theta\right\}
$$

where $T_{i t}$ is an indicator for Eligible firm-years with lagged taxable income above

\footnotetext{
${ }^{9}$ In reality, credits and deductions are somewhat more valuable than we suggest here, since we do not account for the fact that firms may use them in other years.
} 
$\$ 200,000$, PostPolicy $y_{t}$ equals one for all years after $2003, \gamma_{i}$ are firm fixed effects, $\lambda_{j t}$ are 3 -digit SIC-by-year effects, and $X_{i t}$ are time-varying firm-level controls.

Equation (2) is a difference-in-differences specification that compares firms above and below the lower bound of the pre-policy phase-out region, before and after the policy-change, controlling for observed and unobserved firm-level heterogeneity. ${ }^{10}$ The parameter $\beta_{2}$ measures the difference in $\mathrm{R} \& \mathrm{D}$ expenditures between eligible and ineligible firms before 2004. Because the model includes firm-effects, $\beta_{2}$ is identified by firms that cross the eligibility threshold, and have lagged taxable income above $\$ 200,000$ during the pre-policy time period. Similarly, the average change in $R \& D$ expenditures for firms that cross the eligibility threshold during the post-policy period is $\left(\beta_{1}+\beta_{2}\right)$. The parameter $\beta_{1}$ captures the pre- versus post-policy difference in the association between eligibility and $\mathrm{R} \& \mathrm{D}$ spending. We interpret $\beta_{1}$ as an intent-to-treat parameter that measures the average impact of raising the expenditure limit.

The key assumption for causal interpretation of $\beta_{1}$ is that $\beta_{2}$ is a valid estimate of the counter-factual relationship between eligibility (i.e., prior-year taxable income) and $R \& D$ expenditures in the absence of a policy change. Because we include industry-by-year fixed effects to control for aggregate time-trends, the main threat to causal inference is an omitted variable that leads to an upward shift in $\beta_{2}$ around the same time as the policy change. To address this concern, we estimate a version of (2) that replaces PostPolicy $t$ with a set of calendar-year dummies (leading to a separate $\beta_{1}$ parameter for each year of the panel) and show that crossing the eligibility threshold has no impact on R\&D expenditures before the 2004 policy-change.

The reduced-form parameter $\beta_{1}$ measures the impact of the policy change, but not firms' sensitivity to the after-tax cost of R\&D. We can use our estimates,

\footnotetext{
${ }^{10}$ Because eligibility is a function of prior-year taxable income, (2) is not a standard difference-indifferences estimator. In particular, we never observe the average difference in outcomes for two firms with the same prior-year income but different SRED eligibility limits in a given year. Rather, our model compares the association between R\&D and having prior-year taxable income in the relevant range before and after a change in SRED policy.
} 
however, to calculate an implied user-cost elasticity that is comparable to other published results. Suppose $A^{d}$ is the present value of deductions and depreciation allowances, and $A^{c}$ is the value of tax credits, so the after-tax cost of a $\$ 1$ investment is $1-A^{d}-A^{c}$. In Canada, $A^{d}=\tau$, the corporate tax rate, because R\&D expenditures (including for capital) are fully deductible. We also have $A^{c}=\rho(1-\tau)$ because R\&D tax credits are taxable income. The Hall-Jorgensen formula for the steady-state after-tax R\&D user cost is then

$$
U=(r+\delta) \frac{\left(1-A^{d}-A^{c}\right)}{1-\tau}=(r+\delta)(1-\rho)
$$

where $r$ is the real return to the marginal R\&D investment, and $\delta$ is the depreciation rate of the R\&D capital stock. ${ }^{11}$ Equation (3) shows that under SRED, the after-tax R\&D user cost depends upon the credit rate, but not deductions or the corporate tax rate, because the latter two quantities are equal. ${ }^{12}$

The user-cost elasticity of $\mathrm{R} \& \mathrm{D}$ is $d \ln (R) / d \ln (U)$. For the numerator of this expression, we can substitute $d \ln (E[R]) / d T_{i t}=\beta_{1}$. The denominator can be found by substituting $\rho$ into equation (3). For zero-tax-liability firms that would have crossed the original expenditure limit threshold, $d \ln (U) / d T_{i t}=-d U / U=$ $-0.35 / 0.65$, while firms with tax liability have $d \ln (U) / d T_{i t}=-0.15 / 0.65$. Thus, if $s$ percent of eligible firms are in the shaded regions of Figure 1, and $p$ percent of those firms have current tax liability, the implied user cost elasticity is

$$
\frac{d \ln (E[R])}{d \ln (E[U])}=\frac{0.65 * \beta_{1} / s}{[0.20 * p-0.35]}
$$

\footnotetext{
${ }^{11}$ Derivations and extensions of this formula can be found in many papers, including Jorgenson (1963), Hall and Van Reenen (2000), Bloom et al. (2002) and Rao (2016) In practice, because credits are taxed in the period after they are consumed, the exact formula for SRED is $U=(r+\delta)\left\{1-\rho-\frac{r \rho \tau}{(1-\tau)(1+r)}\right\}$, where the third term reflects the benefits of deferring the tax on credits for one year. In our calculations, we assume that $r=0.05$ and $\tau=0.2$, though it makes no practical difference if we simply ignore the third term inside the braces.

${ }^{12}$ Of course, deductions remain valuable to firms that would otherwise have to capitalize their R\&D expenditures, because capitalization leads to $A^{d}<\tau$ which implies a higher after-tax user cost.
} 
Intuitively, $\beta_{1} / s$ is the average treatment effect for treated firms, which is divided by the percentage change in R\&D user costs to obtain an elasticity. Because $s$ is derived from a counter-factual policy — applying the pre-2004 expenditure limit to post-2004 tax and R\&D spending levels - we can compute implied elasticities even though very few firms actually cross the expenditure limit.

Finally, consider how this framework can be used to examine the role of fixed costs in small firms' responsiveness to R\&D tax credits. Conceptually, fixed costs imply a discontinuous jump in the R\&D supply curve. One source of fixed costs is specialized machinery and equipment. We expect firms that have recently made investments in R\&D-related capital to have a larger supply of "benchready" projects. Having already incurred the sunk costs of capacity building, they should be more responsive to a change in the after-tax cost of $\mathrm{R} \& \mathrm{D}$. To test this hypothesis, we estimate a triple-diffs version of equation (2) that interacts $T_{i t}$ PostPolicy $t$ with an indicator for pre-2004 R\&D capital investment.

Small firms also may view hiring new scientists or engineers as a fixed cost. If R\&D capital accumulates within employees, hiring is based on the expectation that these knowledge workers will be retained over the long-term. Tax credits can mitigate the cost of hiring, but not by enough if potential future research projects are improbable and thus cause high expected rates of worker turnover. One alternative to hiring a new researcher is to outsource $R \& D$ projects to a contractor. Firms that face significant fixed costs of hiring but have a supply of one-off projects with an expected return near their hurdle rate may respond to a decrease in the after-tax cost of $R \& D$ by increasing their contract $R \& D$ spending. Thus, we can learn about the importance of fixed costs by comparing estimates of $\beta_{1}$ when the outcome variable is $R \& D$ wages to estimates when the outcome is contract $\mathrm{R} \& \mathrm{D}$ expenditures. 


\section{Data and Measures}

Our data come from the tax records of the Canada Revenue Agency (CRA) for all firms claiming SRED credits during the 2000 to 2007 sample period. Our estimation sample includes all firms that operated as CCPCs throughout the sample period and claimed R\&D tax credits at least once between 2000 and 2003 . We also limit the sample to firms that operated in only one province throughout the sample period to ensure that our analysis is not complicated by having to consider how firms active in multiple jurisdictions might geographically re-allocate their $R \& D$ activity in response to differences in provincial R\&D support. ${ }^{13}$ This yields an unbalanced panel of 7,239 firms and 48,638 firm-year observations. Fifty percent of these firms are in service industries, 29 percent in manufacturing industries, and the remaining 21 percent are in other sectors (primarily agriculture).

Table 1 provides summary statistics for our estimation sample. Total annual SRED-eligible R\&D expenditures averaged $\$ 82,887$ per year, which implies that aggregate annual R\&D spending for the firms in our estimation sample was roughly $\$ 600$ million. ${ }^{14}$ Sixty-six percent of a representative firm's annual expenditures (or $\$ 55,217$ ) reflect wages paid to $R \& D$ personnel. Seventeen percent of R\&D expenditures (or $\$ 14,077$ ) were spent on contract research. Contract research reflects expenditures on the same type of activities that would qualify for SRED benefits if undertaken in-house. Tax credits for contract research are generally allocated to the client, although expenditures in excess of the value of a contract may be allocated to the contractor. Expenditures on R\&D capital were the smallest component of $\mathrm{R} \& \mathrm{D}$ spending, accounting for only $\$ 3,022$, or about 3.6 percent of overall expenditures. Conditional on claiming R\&D capital, however, the average expenditure was about $\$ 27,000$. The remaining 13 percent

\footnotetext{
${ }^{13}$ We also exclude any firm that is associated at any time during our sample period with any other firm. Under the SRED program, associated firms must share a common expenditure limit and must divide room under this limit. To simplify analysis, firms in such sets are not included in the sample.

${ }^{14}$ Thus, if SRED produced a 10-15 percent increase in aggregate R\&D for firms in our sample, it would amount to incremental spending of $\$ 60$ to $\$ 90$ million. We do not view this amount as likely to merit investigation of general equilibrium effects or crowding out in the market for R\&D labor.
} 
of total $R \& D$ spending is highly correlated with $R \& D$ Wages, and we interpret this residual spending as overhead. ${ }^{15}$

Table 1-Summary Statistics

\begin{tabular}{lcccc}
\hline Variable & Mean & SD & Min & Max \\
\hline R\&D Indicator & 0.590 & 0.492 & 0.0 & 1.0 \\
Total R\&D & 82,887 & 216,352 & 0.0 & $>6.5 \mathrm{M}$ \\
R\&D Wages & 55,217 & 147,591 & 0.0 & $>3.5 \mathrm{M}$ \\
R\&D Contracts & 14,077 & 63,350 & 0.0 & $>2.5 \mathrm{M}$ \\
R\&D Capital & 3,022 & 27,868 & 0.0 & $>2.0 \mathrm{M}$ \\
Non-R\&D Investment & 78,420 & 368,447 & 0.0 & $>35 \mathrm{M}$ \\
& Tax Variables & & \\
\hline Eligible & 0.073 & 0.260 & 0.0 & 1.0 \\
Eligible X Post-policy & 0.048 & 0.214 & 0.0 & 1.0 \\
Marginal credit Rate & 0.345 & 0.010 & 0.0 & 0.35 \\
Zero-tax-liability & 0.568 & 0.495 & 0.0 & 1.0 \\
Eligible X Zero-tax & 0.012 & 0.141 & 0.0 & 1.0 \\
& Control Variables & & \\
\hline Pre-policy R\&D Capital & 0.238 & 0.426 & 0.0 & 1.0 \\
Total revenues ${ }^{\dagger}$ & 1.166 & 3.822 & $<0.0$ & $>200 \mathrm{M}$ \\
Total assets ${ }^{\dagger}$ & 1.155 & 2.805 & $<0.0$ & $>150 \mathrm{M}$ \\
Total liabilities ${ }^{\dagger}$ & 0.769 & 1.630 & 0.0 & $>50 \mathrm{M}$ \\
\hline \hline
\end{tabular}

$\dagger$ Millions of nominal Canadian dollars. All statistics based on an unbalanced panel of $\mathrm{N}=48,638$ firm-year observations. Disclosure rules prevent reporting max and min for all variables.

Our main explanatory variables are a pair of dummies for eligibility before and after the policy change. The dummy variable Eligible $\left(T_{i t}\right)$ equals one in any year when a firm's prior-year taxable income falls between $\$ 200$ and $\$ 500$ thousand the range of taxable income over which the expenditure limit increased as a result of the change in SRED (see Figure 1). We also create a variable PostPolicy that equals one in any year after the SRED eligibility limits were changed. The center panel in Table 1 shows that 7.3 percent of all observations are eligible, and of

\footnotetext{
${ }^{15}$ A two-way fixed effects regression of R\&D Wages on "other" R\&D expenditures produces a coefficient of 0.16 with $\mathrm{t}=10.71$.
} 
those, 4.8 percent are treated (eligible after 2004). By far, the main reason why firms are not eligible is that their taxable income was less than $\$ 200$ thousand.

The average credit rate in our sample is 34.5 percent, indicating that almost all firms receive the fully refundable 35 percent credit. More than half of the firm-year observations have no tax liability. The zero-tax-liability share drops to around 16 percent, however, if we condition on eligibility $(0.012 / 0.073 \approx 16.4 \%)$.

Finally, the bottom panel in in Table 1 provides summary statistics for several additional controls. Roughly 24 percent of the firms in our sample made Prepolicy RESD Capital investments. We use this variable as a proxy for fixed cost reduction. Our models also include revenues, assets and liabilities as time-varying controls. The table shows that, on average, firms in our sample had $\$ 1.2$ million in revenue and a similar amount of accounting assets.

\section{Results}

\section{A. The Impact of REDD Tax Credits}

Figure 2 provides some graphical intuition for our main result. To create the figure, we estimate a two-way fixed-effects model (i.e., a linear regression of Total $\mathrm{R} \& \mathrm{D}$ on a full set of firm and year effects) and then use a local polynomial regression to plot the mean of the residuals from that regression against prior-year taxable income. Recall that the change in the SRED expenditure limit formula potentially lowers the after-tax cost of $R \& D$ for firms with prior-year taxable income between $\$ 200$ and $\$ 500$ thousand. So we expect to see an increase in the residual part of $R \& D$ expenditures for firms making more than $\$ 200$ thousand in the post-policy period. This is exactly what we observe in Figure 2. ${ }^{16}$

We now turn to a regression that decomposes the residuals graphed in Figure 2. Table 2 presents estimates of the impact of expenditure limit reformulation on

\footnotetext{
${ }^{16}$ While it would be reassuring to observe a return to the same mean-zero baseline for firms above $\$ 500$ thousand, we do not have enough data to reliably estimate the mean residual on that portion of the support of the prior-year taxable income distribution.
} 


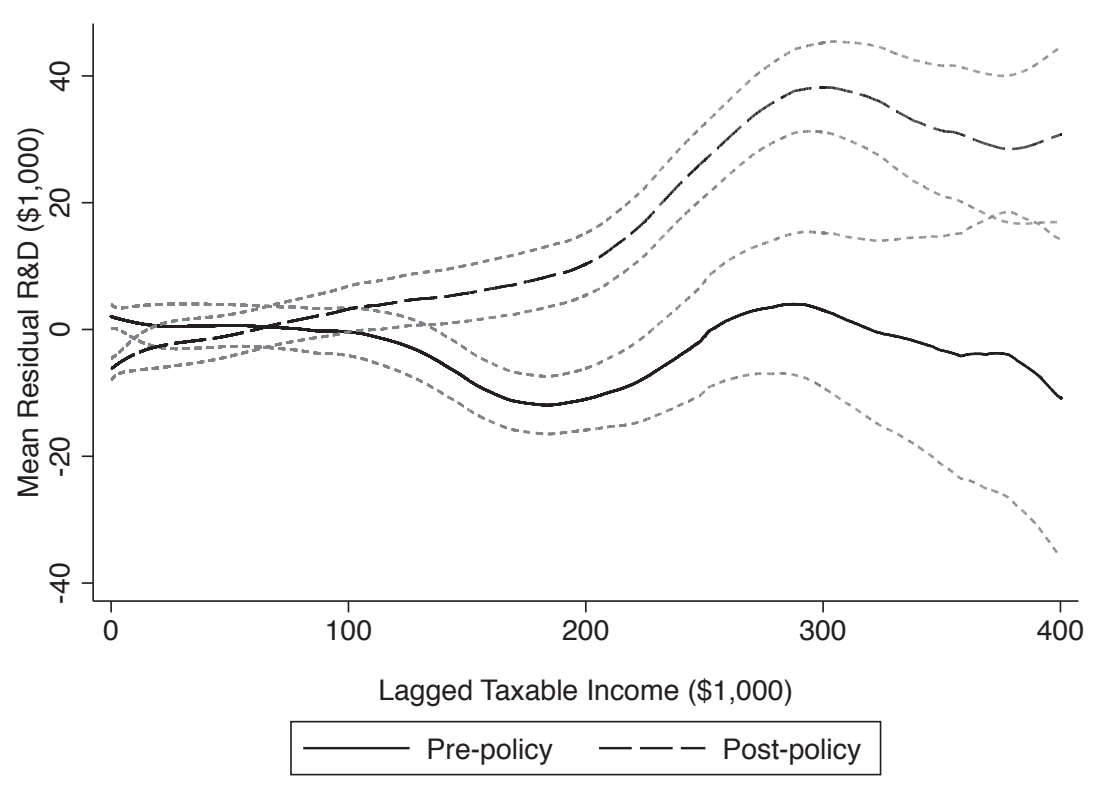

Figure 2. Pre- \& Post-Policy R\&D

Note: Figure 2 plots fitted values and 95 percent confidence intervals from a local polynomial regression. The outcome variable is residual R\&D obtained by estimating a two-way fixed effects model of Total $\mathrm{R} \& \mathrm{D}$ spending that includes firm and year effects. The explanatory variable is prior-year taxable income, which determines the location of the expenditure limit (see Figure 1).

Total R\&D from Poisson-QML estimation of equation (2). A Poisson estimator handles the many cases where $R_{i t}=0$ more naturally than a log-log specification, and QML simply means that we uses robust standard errors (clustered by firm) to correct for over-dispersion, leading to asymptotically correct confidence intervals. Estimates of $\beta_{1}$, the impact of the change in the expenditure limit, appear in the first row of the table.

Column 1 contains estimates from a parsimonious specification with only firm effects plus dummies for Eligible, PostPolicy, and their interaction. The coefficient of 0.17 in the first row can be interpreted as an elasticity: crossing the eligibility threshold produces a 17 percent greater increase in $R \& D$ expenditures after the policy is in place than before. This effect is statistically significant at the 1 percent level. The coefficient on Eligible shows that firms above the threshold 
had greater $R \& D$ expenditures than firms below the threshold, even before the policy change. The coefficient on PostPolicy shows that there was a secular trend toward more $R \& D$ expenditures over this period, even among firms that did not change eligibility status. Nevertheless, the Eligible x PostPolicy interaction shows that in the post-policy time period, the average difference in Total $R \& D$ expenditures between eligible and ineligible firms is about 50 percent larger that the average difference during the baseline period.

Table 2-Impacts of the Change in SRED Eligibility Limits

\begin{tabular}{|c|c|c|c|c|c|c|}
\hline \multicolumn{7}{|c|}{$\begin{array}{c}\text { Specification: Poisson QML Regression } \\
\text { Unit of Analysis: Firm-Year }\end{array}$} \\
\hline Outcome Variable & $\begin{array}{l}\text { Total } \\
\text { R\&D } \\
(1)\end{array}$ & $\begin{array}{l}\text { Total } \\
\text { R\&D } \\
(2)\end{array}$ & $\begin{array}{l}\text { Total } \\
\text { R\&D } \\
(3)\end{array}$ & $\begin{array}{l}\text { R\&D } \\
\text { Wages } \\
(4)\end{array}$ & $\begin{array}{l}\text { R\&D } \\
\text { Contracts } \\
(5)\end{array}$ & $\begin{array}{l}\text { Non-R\&D } \\
\text { Investment } \\
\quad(6)\end{array}$ \\
\hline Eligible X Post policy & $\begin{array}{l}0.17 \\
(0.05)\end{array}$ & $\begin{array}{c}0.17 \\
(0.05)\end{array}$ & $\begin{array}{l}0.17 \\
(0.04)\end{array}$ & $\begin{array}{c}0.11 \\
(0.04)\end{array}$ & $\begin{array}{c}0.34 \\
(0.09)\end{array}$ & $\begin{array}{c}0.14 \\
(0.08)\end{array}$ \\
\hline Eligible & $\begin{array}{c}0.09 \\
(0.04)\end{array}$ & $\begin{array}{c}0.07 \\
(0.04)\end{array}$ & $\begin{array}{l}0.01 \\
(0.03)\end{array}$ & $\begin{array}{l}0.02 \\
(0.04)\end{array}$ & $\begin{array}{l}0.03 \\
(0.08)\end{array}$ & $\begin{array}{l}0.05 \\
(0.06)\end{array}$ \\
\hline Post-policy & $\begin{array}{c}0.11 \\
(0.02)\end{array}$ & & & & & \\
\hline $\begin{array}{l}\text { Firm FE } \\
\text { Industry-Year FE } \\
\text { Controls }\end{array}$ & $\begin{array}{l}\text { Yes } \\
\text { No } \\
\text { No }\end{array}$ & $\begin{array}{l}\text { Yes } \\
\text { Yes } \\
\text { No }\end{array}$ & $\begin{array}{l}\text { Yes } \\
\text { Yes } \\
\text { Yes }\end{array}$ & $\begin{array}{l}\text { Yes } \\
\text { Yes } \\
\text { Yes }\end{array}$ & $\begin{array}{l}\text { Yes } \\
\text { Yes } \\
\text { Yes }\end{array}$ & $\begin{array}{l}\text { Yes } \\
\text { Yes } \\
\text { Yes }\end{array}$ \\
\hline $\begin{array}{l}\text { Observations } \\
\text { Number of firms } \\
\text { Mean of outcome } \\
\text { Psuedo-R2 }\end{array}$ & $\begin{array}{c}48,638 \\
7,239 \\
82,887 \\
0.75 \\
\end{array}$ & $\begin{array}{c}48,638 \\
7,239 \\
82,887 \\
0.75 \\
\end{array}$ & $\begin{array}{c}48,638 \\
7,239 \\
82,887 \\
0.82 \\
\end{array}$ & $\begin{array}{c}38,748 \\
5,806 \\
69,310 \\
0.84 \\
\end{array}$ & $\begin{array}{c}36,235 \\
5,378 \\
18,895 \\
0.68 \\
\end{array}$ & $\begin{array}{c}46,809 \\
6,895 \\
81,732 \\
0.75 \\
\end{array}$ \\
\hline \multicolumn{7}{|c|}{ Implied User-cost Elasticity $^{\dagger}$} \\
\hline $\begin{array}{l}\text { Lower Bound } \\
(s=0.59, p=0.43)\end{array}$ & $\begin{array}{l}-0.71 \\
(0.21)\end{array}$ & $\begin{array}{l}-0.71 \\
(0.21)\end{array}$ & $\begin{array}{l}-0.71 \\
(0.17)\end{array}$ & $\begin{array}{l}-0.46 \\
(0.17)\end{array}$ & $\begin{array}{l}-1.42 \\
(0.38)\end{array}$ & \\
\hline $\begin{array}{l}\text { Upper Bound } \\
(s=0.11, p=0.65)\end{array}$ & $\begin{array}{l}-4.57 \\
(1.34)\end{array}$ & $\begin{array}{l}-4.57 \\
(1.34)\end{array}$ & $\begin{array}{l}-4.57 \\
(1.07)\end{array}$ & $\begin{array}{l}-2.95 \\
(1.07)\end{array}$ & $\begin{array}{l}-9.13 \\
(2.42)\end{array}$ & \\
\hline
\end{tabular}

In Column 2, we add 3-digit SIC industry-by-year effects, which absorb the main effect of PostPolicy, but produce no change in our estimate of $\beta_{1}$. In Column 3, we add the the log of Assets, Liabilities and Revenue as time-varying 
firm-level controls. Adding these size controls removes any correlation between eligibility and $R \& D$ expenditures during the pre-policy period. Even with these controls, however, we continue to find a highly significant $(p<0.001)$ increase in $R \& D$ expenditures at the eligibility threshold following the 2004 expenditure limit reformulation. ${ }^{17}$

Columns 4 through 6 in Table 2 examine different outcome variables. ${ }^{18}$ Column (4) shows an 11 percent increase for RED Wages. Column (5) reports that Contract $R \mathscr{E} D$ expenditures increase by 34 percent. Because wages account for two-thirds of R\&D spending, the dollar-denominated impact on wages and contracts are very similar (see Table 5). The scale-free coefficient on Contract RES is twice that of Total $R \mathscr{E} D$, however, and three times the size of the $R \mathscr{E} D$ Wages effect. $^{19}$

Unfortunately, our data on the R\&D wage bill does not distinguish between hiring additional employees (real effects) and paying higher R\&D wages (crowding out). If starting a new project requires hiring a new $R \& D$ employee, however, we expect that fixed costs reduce the impact of a more favorable tax credit policy. Intuitively, these small firms face an integer constraint - new employees must be hired one at a time - and an incremental unit of R\&D labor is not a negligible expenditure for firms whose average $\mathrm{R} \& \mathrm{D}$ wage bill is $\$ 55,217$ (roughly the starting salary for a single engineer). ${ }^{20}$

Our discussions with managers and tax practitioners also suggest several ways that firm-level fixed costs might influence the decision to outsource R\&D. First, if managers view both their research budget and the quantity of permanent R\&D

\footnotetext{
${ }^{17}$ Estimates from OLS regressions using $\log ($ Total $R \& D)$ as the outcome variable yield similar results but are sensitive to the treatment of observations with zero reported R\&D expenditure (see Table B-6 in the online appendix). J. M. C. Santos-Silva and Tenreyro (2006) explain how log-linear models can produce biased estimates, particularly in applications with many zeroes, and suggest using Poisson-QML as an alternative.

${ }^{18}$ Sample sizes change for different outcomes because our models contain a multiplicative fixed effect and therefore all observations with all-zero outcomes are dropped. As a robustness check, we re-run all regressions with the outcome set to $\max \left\{1, R_{i t}\right\}$ and obtain identical results.

${ }^{19}$ We also estimate the impacts for R\&D Capital and Other R\&D spending. Neither effect is statistically different from zero.

${ }^{20}$ The web site talentegg.ca reports starting salaries for Canadian engineers between $\$ 57,000$ and $\$ 84,000$, with a median of roughly $\$ 65,000$ in 2013 , or about $\$ 60,000$ in 2008 dollars.
} 
labor as fixed factors, contracting provides a way to exhaust the budget when tax incentives reduce the cost of internal $R \& D$. Second, contract $R \& D$ may provide a relatively transparent (i.e., easy to document) form of R\&D expenditure. Thus, even if a firm could allocate its current employees to a new research project, managers may favor contract $R \& D$ because they believe use of contracted $R \& D$ services facilitates the assessment of these expenditures for purposes of the tax credit. ${ }^{21}$ Finally, contractors can pass any SRED-related tax savings to clients in at least two different ways: by allowing a client to claim the credits directly or by claiming the credit themselves and passing the savings to clients in the form of lower prices.

Table 2 column 6 considers whether our main results might come from relabeling of other types of investment as R\&D. For example, Chen et al. (2017) suggest that roughly 30 percent of the measured response to a Chinese fiscal R\&D incentive comes from re-labeling. Column 6 examines changes in Non$R \mathscr{E} D$ Investment. If the observed increase in Total $R E B D$ reflects re-labeling of expenditures that firms would have made even in the absence of a SRED program change, we would expect a reduction in other types of investment. Instead, we find a statistically insignificant 14 percent increase in non-R\&D capital expenditure for eligible firms in the post-policy period. ${ }^{22}$

Finally, the bottom panel of Table 2 reports implied user-cost elasticities for different combinations of $s$ and $p$, based on equation (4), along with standard errors calculated via the delta method. In the top row, we use the overall sample means. Specifically we assume any firm with positive R\&D faces a binding expenditure limit $(s=0.59)$, and that 57 percent of those firms have no tax liability $(p=0.43)$, which leads to an implied elasticity of -0.71 for Total $R E \mathcal{E}$, -0.46 for $R \& D$ Wages, and -1.42 for $\mathrm{R} \& \mathrm{D}$ Contracts. We see these figures as a

\footnotetext{
${ }^{21}$ We find supporting evidence for this story by examining related party (i.e., non-arms length) contract $R \& D$ expenditures and finding that they are a significant piece of the overall contract $R \& D$ effect.

${ }^{22}$ If we change the outcome to Non-R\&D Investment / Sales, the coefficient changes sign and remains statistically insignificant, suggesting that the positive estimate in Table 2 column 6 is not driven by complementarities between R\&D and non-R\&D spending, or a large income or scale effect.
} 
lower bound on the magnitude of the true user cost elasticity, because the credit rate does not actually change for most firms (suggesting $s$ should be smaller), and because eligible firms are more likely to pay tax (suggesting $p$ should be larger).

Our second set of user cost calculations assume $s=0.11$, which is the share of post-policy observations having $\mathrm{R} \& \mathrm{D}$ expenditures above the pre-policy expenditure limit (i.e. the share of eligible firms in the shaded parts of Figure 1). We also assume $p=0.65$, which is the share of firms with current tax liability in this "treated" group. These assumptions imply a user-cost elasticity of -4.57 for Total $R \mathscr{E} D,-2.95$ for $R \mathscr{E} D$ Wages, and -9.13 for Contract $R \mathscr{E} D$. This is a large response. At the same time, the $95 \%$ confidence interval for Total R\&D covers other recent estimates for small and medium-sized firms (e.g. Dechezleprêtre et al., 2016), and the very large elasticity for Contract $R \mathscr{E} D$ reflects substitution from wages to contracts, as well as a lower baseline spending level.

We view the calculations in the bottom row of Table (2) as an upper bound on the true user-cost elasticity, because our data show that R\&D increases even among firms that do not cross the pre-2004 expenditure limit. In particular, if we discard all observations with R\&D expenditures above the pre-2004 expenditure limit, our baseline empirical model still finds positive and statistically significant impacts of the policy change. ${ }^{23}$ This suggests that the true value of $s$ is greater than $11 \%$, and is an interesting finding in its own right, because it implies that firms respond not only to their marginal tax rates, but also the amount of "spending room" they have before exhausting the fully refundable $35 \%$ SRED credits.

\section{B. Trends and Timing}

One concern with our diff-in-diffs design is that firms may have anticipated the policy-change and tried to manipulate their treatment status before its implementation. As a practical matter, it is unclear how firms that anticipate a policy change should respond. Zero-tax-liability firms with $R \& D$ spending in the vicinity

\footnotetext{
${ }^{23}$ We report these estimates are in the online appendix Table B-3.
} 
of the pre-policy expenditure limit may delay some R\&D spending to take advantage of the shift. On the other hand, firms with taxable income that anticipate large $R \& D$ expenditures will typically want to accelerate their spending in order to create a current-year deduction and an increase in the next year's expenditure limit threshold. Thus, the bias could go in either direction. As a robustness test, we re-estimated our baseline model using a sample that discards all data from the years 2003 and 2004. For that sample, the coefficient on Eligible X Post-policy increases to 0.22 , with a standard error of 0.06 (not significantly different from our baseline estimates). ${ }^{24}$ We conclude that any bias from firms anticipating the SRED policy change was small, and likely caused us to under-estimate the impact of the policy.

A second concern with our diff-in-diffs research design is that $\beta_{1}$ may be measuring a secular trend in $\beta_{2}$. In other words, the treatment effect may reflect a pre-existing trend in the relationship between $R \& D$ expenditures and eligibility. This concern motivates the standard "parallel trends" falsification test, which we implement via an event-study specification. Specifically, we estimate

$$
E\left[R_{i t} \mid T_{i t}, X_{i t}\right]=\exp \left\{T_{i t} \beta_{t}+\gamma_{i}+\lambda_{j t}+X_{i t} \theta\right\}
$$

where the $\beta_{t}$ are year-specific treatment effects that measure the difference in $R \& D$ spending for eligible versus non-eligible firms in each year of the panel. The parallel-trends test is equivalent to a test of the null-hypotheses that $\beta_{t}$ are jointly zero for all $t \leq 2003$. Table 3 reports estimates of $\beta_{t}$ for each of the three main outcomes: Total RED, R\&D Wages and Contract REDD.

In the bottom row of the table, we report tests of the parallel-trends hypothesis. For all three outcomes, we find no statistically significant evidence of a pre-policy trend in $\beta_{1}$. This lends credibility to a causal interpretation of the reduced-

\footnotetext{
${ }^{24}$ Estimation results for a variety of samples that exclude observations from 2003, 2004 and 2005 are provided in Table B-5.
} 
Table 3-Event Study Specification

\begin{tabular}{|c|c|c|c|}
\hline \multicolumn{4}{|c|}{$\begin{array}{l}\text { Specification: Poisson QML } \\
\text { Unit of Analysis: Firm-Year }\end{array}$} \\
\hline Outcome & $\begin{array}{l}\text { Total } \\
\text { R\&D } \\
(1)\end{array}$ & $\begin{array}{l}\text { R\&D } \\
\text { Wages } \\
(2)\end{array}$ & $\begin{array}{l}\mathrm{R} \& \mathrm{D} \\
\text { Contracts } \\
(3)\end{array}$ \\
\hline Eligible X 1[2000] & $\begin{array}{c}0.09 \\
(0.09)\end{array}$ & $\begin{array}{c}0.16 \\
(0.09)\end{array}$ & $\begin{array}{l}-0.07 \\
(0.25)\end{array}$ \\
\hline Eligible X 1[2001] & $\begin{array}{l}-0.02 \\
(0.07)\end{array}$ & $\begin{array}{c}0.00 \\
(0.07)\end{array}$ & $\begin{array}{c}0.10 \\
(0.16)\end{array}$ \\
\hline Eligible X 1[2002] & $\begin{array}{l}-0.07 \\
(0.05)\end{array}$ & $\begin{array}{l}-0.02 \\
(0.05)\end{array}$ & $\begin{array}{l}-0.07 \\
(0.10)\end{array}$ \\
\hline Eligible X 1[2003] & $\begin{array}{c}0.04 \\
(0.04)\end{array}$ & $\begin{array}{c}0.01 \\
(0.04)\end{array}$ & $\begin{array}{c}0.12 \\
(0.12)\end{array}$ \\
\hline Eligible X 1[2004] & $\begin{array}{c}0.07 \\
(0.03)\end{array}$ & $\begin{array}{c}0.07 \\
(0.03)\end{array}$ & $\begin{array}{c}0.14 \\
(0.10)\end{array}$ \\
\hline Eligible X 1[2005] & $\begin{array}{c}0.19 \\
(0.04)\end{array}$ & $\begin{array}{c}0.15 \\
(0.04)\end{array}$ & $\begin{array}{c}0.39 \\
(0.12)\end{array}$ \\
\hline Eligible X 1[2006] & $\begin{array}{c}0.23 \\
(0.04)\end{array}$ & $\begin{array}{c}0.16 \\
(0.04)\end{array}$ & $\begin{array}{c}0.49 \\
(0.13)\end{array}$ \\
\hline Eligible X 1[2007] & $\begin{array}{c}0.19 \\
(0.04)\end{array}$ & $\begin{array}{c}0.11 \\
(0.04)\end{array}$ & $\begin{array}{c}0.45 \\
(0.13)\end{array}$ \\
\hline $\begin{array}{l}\text { Firm Fixed Effects } \\
\text { Industry-Year Effects } \\
\text { Additional controls }\end{array}$ & $\begin{array}{l}\text { Yes } \\
\text { Yes } \\
\text { Yes }\end{array}$ & $\begin{array}{l}\text { Yes } \\
\text { Yes } \\
\text { Yes }\end{array}$ & $\begin{array}{l}\text { Yes } \\
\text { Yes } \\
\text { Yes }\end{array}$ \\
\hline $\begin{array}{l}\text { Pre-trends F-stat } \\
\text { (p-value) }\end{array}$ & $\begin{array}{l}5.59 \\
0.23\end{array}$ & $\begin{array}{l}3.82 \\
0.43\end{array}$ & $\begin{array}{l}2.33 \\
0.68\end{array}$ \\
\hline Observations & 48,638 & 38,748 & 36,235 \\
\hline Total Firms & 7,239 & 5,806 & 5,378 \\
\hline Mean of outcome & 82,887 & 69,310 & 18,895 \\
\hline
\end{tabular}

Notes: Robust standard errors (clustered by firm) in parentheses. Pre-trends F-stat (p-value) is for null hypothesis that $\beta_{2000}$ through $\beta_{2003}$ are jointly equal to zero. All models are estimated using an unbalanced panel of all available firm-years; changes in sample size occur when firms with all-zero outcomes are dropped from the conditional fixed-effects specification. 
form results in Table 2, since the main threat to our identification strategy is an upward trend in the slope of the lagged-earnings-to-R\&D relationship over the entire sample period.

Table 3 also provides evidence on the timing of the policy impacts. In particular, the coefficients in 2003 and 2004 are generally small and statistically significant, while the coefficients for 2005 through 2007 are two or three times larger and statistically significant at conventional levels. The pattern of treatment effects, starting in 2004 and increasing through 2006, also suggests that firms face adjustments costs in their R\&D spending. If that is the case, the true user cost elasticity of $\mathrm{R} \& \mathrm{D}$ will be somewhat larger than our estimates in Table 2, because those coefficients are based on an average that includes the (smaller) short-term response.

\section{Treatment Heterogeneity: Tax Liability and Fixed Costs}

This sub-section estimates a pair of triple-difference models that allow the impact of the SRED policy change to vary across firm-years. We use these models to examine treatment heterogeneity for zero-tax-liability firms, and firms that made pre-2004 R\&D capital investments. Specifically, let the indicator variable $D_{i t}$ divide the estimation sample into two groups according to current-year tax liability or pre-policy R\&D capital investments. We estimate the following regression:

$$
\begin{aligned}
E\left[R_{i t} \mid T_{i t}, D_{i t}, X_{i t}\right] & =\exp \left\{D_{i t} T_{i t} \text { PostPolicy }_{t} \beta_{1}+D_{i t} \text { PostPolicy }_{t} \beta_{2}+\right. \\
D_{i t} T_{i t} \beta_{3} & \left.+T_{i t} \text { PostPolicy }_{t} \beta_{4}+T_{i t} \beta_{5}+D_{i t} \beta_{6}+\gamma_{i}+\lambda_{j t}+X_{i t} \theta\right\}
\end{aligned}
$$

where all of the other variables are defined above. Note that this model contains a full set of two-way interactions, and that the main effects of PostPolicyt are subsumed in year the industry-by-year fixed-effects.

In the first three columns of Table 4 , the indicator $D_{i t}$ is a dummy for firmyear observations with no current tax liability. The Zero-tax dummy variable 
identifies firms that cannot deduct their marginal dollar of R\&D expenditure, and who therefore face a steeper increase in the after-tax cost of R\&D when crossing the expenditure limit threshold. Put differently, these firms benefit not only from a higher credit rate, but also from the refundable nature of SRED credits, because they have exhausted the value of any tax deductions.

The key results for zero-tax-liability firms appear in the top two rows of Table 4. Before the 2004 policy-change, these firms' R\&D spending declined by 16 to 31 percent (relative to firms that pay tax) if they were in the Eligible group, and therefore faced a lower expenditure limit. Adding the coefficients in the top two rows of Table 4 reveals that most of the drop-off for eligible firms with no current tax liability disappeared when the SRED expenditure limits were increased. Another way to interpret these results is to note that the coefficient on Eligible $x$ Policy is the diff-in-diffs estimate for firms that pay tax, whereas the diff-in-diffs estimate for zero-tax-liability firms is found by adding the coefficients on Eligible $x$ Policy and the three-way interaction. This shows that the impact of the SRED policy change was roughly twice as large for zero-tax-liability firms, although the coefficient on the three way interaction is significant at the 5 percent level only for Total RED spending.

In columns 4 through $6, D_{i}$ corresponds to an indicator for firms that made $\mathrm{R} \& \mathrm{D}$ capital investments in the pre-policy period. Because this is a time-invariant explanatory variable, the main effect of $D_{i}$ is absorbed by firm fixed effects. For these models, we exclude firms in the Professional, Scientific and Technical Services sector (NAICS 541) from the estimation sample because we expect fixed costs to be less relevant for R\&D service providers - with a steady flow of projects, there is less chance that specialized assets will sit idle. ${ }^{25}$

If capital expenditures represent a fixed cost that dampens small firms' response

\footnotetext{
${ }^{25}$ Examples of firm types in this industry are engineering and internet consulting companies as well as specialized software development companies. In a previous version of the paper, we estimated tripledifference models that included a three-way interaction for firms in NAICS 541, and found that they were more responsive to the SRED policy change on the intensive margin (R\&D Wages), but not the extensive margin ( $R \& D$ Contracts), relative to firms in other industries. This is the same pattern we find for firms outside NAICS 541 with pre-2004 R\&D Capital investments.
} 
Table 4 - Tax Liability and Fixed Costs

\begin{tabular}{|c|c|c|c|c|c|c|}
\hline \multirow{3}{*}{$\begin{array}{l}\text { Sample } \\
\text { R\&D Outcome Variable }\end{array}$} & \multicolumn{6}{|c|}{$\begin{array}{l}\text { Specification: Poisson QML Regression } \\
\text { Unit of Analysis: Firm-Year }\end{array}$} \\
\hline & \multicolumn{3}{|c|}{ All Firm-Years } & \multicolumn{3}{|c|}{ Non-NAICS 541 Firm-Years } \\
\hline & $\begin{array}{c}\text { Total } \\
(1)\end{array}$ & $\begin{array}{c}\text { Wages } \\
(2)\end{array}$ & $\begin{array}{c}\text { Contracts } \\
(3)\end{array}$ & $\begin{array}{c}\text { Total } \\
(4)\end{array}$ & $\begin{array}{c}\text { Wages } \\
(5)\end{array}$ & $\begin{array}{c}\text { Contracts } \\
(6)\end{array}$ \\
\hline Eligible X Policy X Zero-tax & $\begin{array}{c}0.16 \\
(0.08)\end{array}$ & $\begin{array}{c}0.11 \\
(0.08)\end{array}$ & $\begin{array}{c}0.36 \\
(0.21)\end{array}$ & & & \\
\hline Eligible X Zero-tax & $\begin{array}{l}-0.24 \\
(0.04)\end{array}$ & $\begin{array}{l}-0.16 \\
(0.04)\end{array}$ & $\begin{array}{l}-0.31 \\
(0.08)\end{array}$ & & & \\
\hline Policy X Zero-tax & $\begin{array}{l}-0.08 \\
(0.07)\end{array}$ & $\begin{array}{l}-0.07 \\
(0.07)\end{array}$ & $\begin{array}{l}-0.13 \\
(0.16)\end{array}$ & & & \\
\hline Zero-tax-liability & $\begin{array}{c}0.12 \\
(0.03)\end{array}$ & $\begin{array}{c}0.10 \\
(0.03)\end{array}$ & $\begin{array}{c}0.10 \\
(0.07)\end{array}$ & & & \\
\hline Eligible X Policy X Capital & & & & $\begin{array}{c}0.25 \\
(0.11)\end{array}$ & $\begin{array}{c}0.24 \\
(0.10)\end{array}$ & $\begin{array}{c}0.11 \\
(0.24)\end{array}$ \\
\hline Policy X Capital & & & & $\begin{array}{l}-0.26 \\
(0.06)\end{array}$ & $\begin{array}{l}-0.19 \\
(0.05)\end{array}$ & $\begin{array}{l}-0.22 \\
(0.12)\end{array}$ \\
\hline Eligible X Capital & & & & $\begin{array}{l}-0.15 \\
(0.08)\end{array}$ & $\begin{array}{l}-0.16 \\
(0.08)\end{array}$ & $\begin{array}{l}-0.05 \\
(0.17)\end{array}$ \\
\hline Eligible X Policy & $\begin{array}{c}0.04 \\
(0.05)\end{array}$ & $\begin{array}{c}0.02 \\
(0.05)\end{array}$ & $\begin{array}{c}0.11 \\
(0.12)\end{array}$ & $\begin{array}{c}0.02 \\
(0.05)\end{array}$ & $\begin{array}{l}-0.05 \\
(0.05)\end{array}$ & $\begin{array}{c}0.34 \\
(0.16)\end{array}$ \\
\hline Eligible & $\begin{array}{c}0.07 \\
(0.04)\end{array}$ & $\begin{array}{c}0.07 \\
(0.04)\end{array}$ & $\begin{array}{c}0.11 \\
(0.10)\end{array}$ & $\begin{array}{c}0.08 \\
(0.04)\end{array}$ & $\begin{array}{c}0.11 \\
(0.04)\end{array}$ & $\begin{array}{l}-0.02 \\
(0.12)\end{array}$ \\
\hline $\begin{array}{l}\text { Firm Fixed Effects } \\
\text { Industry-Year FEs } \\
\text { Additional controls }\end{array}$ & $\begin{array}{l}\text { Yes } \\
\text { Yes } \\
\text { Yes } \\
\end{array}$ & $\begin{array}{l}\text { Yes } \\
\text { Yes } \\
\text { Yes } \\
\end{array}$ & $\begin{array}{l}\text { Yes } \\
\text { Yes } \\
\text { Yes } \\
\end{array}$ & $\begin{array}{l}\text { Yes } \\
\text { Yes } \\
\text { Yes } \\
\end{array}$ & $\begin{array}{l}\text { Yes } \\
\text { Yes } \\
\text { Yes } \\
\end{array}$ & $\begin{array}{l}\text { Yes } \\
\text { Yes } \\
\text { Yes } \\
\end{array}$ \\
\hline Psuedo-R2 & 0.81 & 0.84 & 0.67 & 0.81 & 0.83 & 0.66 \\
\hline Observations & 48,638 & 38,748 & 36,235 & 34,595 & 25,964 & 26,133 \\
\hline Total Firms & 7,239 & 5,806 & 5,378 & 5,051 & 3,837 & 3,793 \\
\hline NAICS 541 / Capital Firms & & & & 879 & 820 & 690 \\
\hline Mean of outcome & 82,887 & 69,310 & 18,895 & 66,176 & 57,108 & 13,393 \\
\hline
\end{tabular}

Notes: Robust standard errors (clustered by firm) in parentheses. All models are estimated using an unbalanced panel of all available firm-years; changes in sample size occur when firms with all-zero outcomes are dropped from the conditional fixed-effects specification. The mean value of the outcome variable is calculated for all firm-years used in the estimation. 
to a change in the after-tax cost of $R \& D$, then firms with pre-policy $R \& D$ capital investment should have a larger response to the policy change, because those fixed costs have already been sunk. This is exactly what we see in columns 4 and 5 , where firms that made ex ante $\mathrm{R} \& \mathrm{D}$ capital expenditures increase Total $R \mathscr{E} D$ spending by 25 percent more and $R \& D$ Wages by 24 percent more than other eligible firms in the post-policy period. ${ }^{26}$ The fact that we find no statistically significant change on the extensive margin ( $R \& D$ contracts) is also consistent with the fixed cost hypothesis. In particular, the results in Table 2 show that, on average, contract spending is more responsive to the policy shift than wages. But once the necessary fixed costs are sunk, these results suggest that more of the incremental R\&D spending shifts back inside the firm.

\section{Decomposition of Policy Impacts}

Before concluding, we use the estimates reported above to decompose the overall impact of the policy-change into a series of dollar denominated effects for firms with and without tax liability. The top panel in Table 5 shows the firm-level impacts of expenditure limit reformulation. To compute these figures, we multiplied the pre-2004 mean of each outcome variable by our diff-in-diff estimates of the policy impact. For the All Firms column, we use estimates from Table 2, columns (3) to (5). For the Taxes Owed and Zero Tax Liability columns, we use estimates from Table 4, columns (1) and (2). The bottom panel in Table 5 shows the aggregate impact of the policy along each margin. These numbers are calculated by multiplying the figure in the top panel by the average annual post-policy observation count in each cell.

The results in the top panel of Table 5 show that, in dollar terms, zero-taxliability firms increased their annual R\&D spending by roughly an order of magnitude more than firms owing tax in the current year. This reflects a difference in baseline expenditures - firms without tax liability spend roughly 2.5 times more

\footnotetext{
${ }^{26}$ Table B-4 shows that we obtain very similar results using a balanced panel.
} 
Table 5-Marginal Effects at Sample Means

\begin{tabular}{|c|c|c|c|}
\hline & $\begin{array}{c}\text { All } \\
\text { Firms }\end{array}$ & $\begin{array}{l}\text { Taxes } \\
\text { Owed }\end{array}$ & $\begin{array}{l}\text { Zero Tax } \\
\text { Liability }\end{array}$ \\
\hline \multicolumn{4}{|c|}{ Firm-level Impact ( $\$$ per year) } \\
\hline Total R\&D & $\begin{array}{l}27,419 \\
(8,065)\end{array}$ & $\begin{array}{c}4,991 \\
(6,239)\end{array}$ & $\begin{array}{c}64,597 \\
(23,384)\end{array}$ \\
\hline R\&D Wages & $\begin{array}{l}11,668 \\
(4,243)\end{array}$ & $\begin{array}{c}1,746 \\
(4,365)\end{array}$ & $\begin{array}{c}24,665 \\
(14,032)\end{array}$ \\
\hline R\&D Contracts & $\begin{array}{c}8,977 \\
(2,376) \\
\end{array}$ & $\begin{array}{c}2,245 \\
(2,449) \\
\end{array}$ & $\begin{array}{l}24,911 \\
(8,605) \\
\end{array}$ \\
\hline \multicolumn{4}{|c|}{ Aggregate Impact (\$Million per year) } \\
\hline Total R\&D & $\begin{array}{l}16.1 \\
(4.7)\end{array}$ & $\begin{array}{c}2.5 \\
(3.1)\end{array}$ & $\begin{array}{c}6.0 \\
(2.2)\end{array}$ \\
\hline R\&D Wages & $\begin{array}{c}6.8 \\
(2.5)\end{array}$ & $\begin{array}{c}0.9 \\
(2.2)\end{array}$ & $\begin{array}{c}2.3 \\
(1.3)\end{array}$ \\
\hline R\&D Contracts & $\begin{array}{c}5.3 \\
(1.4)\end{array}$ & $\begin{array}{c}1.1 \\
(1.2)\end{array}$ & $\begin{array}{c}2.3 \\
(0.8)\end{array}$ \\
\hline
\end{tabular}

Notes: Calculations for All Firms based on estimates in Table 2, columns (3) to (5). Calculations for sub-samples with and without tax liability based on estimates in Table 4, columns (1) to (3). Standard errors in parentheses. 
on $\mathrm{R} \& \mathrm{D}$ - and a larger impact of the SRED policy change. The top panel also shows that for each type of firm (i.e. with and without tax liability), spending on contracts increased by roughly the same amount as as the R\&D wage bill. The bottom panel of Table 5 shows that zero-tax-liability firms account for more than half of the aggregate impact of the SRED expenditure limit reformulation. Overall, the calculations in Table 5 indicate that firms that face no tax liability, and have therefore exhausted any benefit from deductibility of R\&D expenditures, are very responsive to the refundable SRED credits. This finding suggests that the recent change in the U.S. tax policy described in the introduction may have a substantial impact on small firm R\&D expenditures.

\section{Conclusions}

We exploit a change in eligibility rules for $R \& D$ investment tax credits under the Canadian SRED policy to estimate the impact of this program on small-firm R\&D expenditures. Privately owned firms that became eligible to benefit from a refundable 35 percent $R \& D$ tax credit on a greater amount of qualified $R \& D$ expenditures increased their R\&D spending by an average of 17 percent, compared to before the program. This corresponds to an R\&D user cost elasticity between -0.7 and -4.57 . Our findings contribute to a growing body of evidence suggesting that tax incentives can induce private $R \& D$ expenditures, even among small and young firms (e.g., Dechezleprêtre et al., 2016). While small firms account for a modest share of aggregate $R \& D$, they may have a comparative advantage in specific types of innovation, and linking our findings to innovation outcomes is an important topic for future research.

This study also provides several pieces of evidence that fixed costs play an important role in how small firms respond to a change in the after-tax cost of R\&D. First, we decompose R\&D spending into wages and contracts, and show that estimated user-cost elasticities are much larger for contract R\&D expenditures. Second, we show that the response to the SRED policy change was larger 
among firms that recently made R\&D-related capital investments, and that for those firms, the response was stronger for the $R \& D$ wage bill than for contract expenditures. Many of the firms in our sample are small enough that they may not be able to fully utilize an additional scientist or engineer, and these findings suggest that such firms use external contract R\&D to avoid the fixed costs of launching a new project internally, but shift back to internal work after capacity is in place.

Beyond providing new evidence on fixed costs and the response of small firms to the R\&D tax credit, our findings are useful for projecting the effects of recent U.S tax policy changes in this area. Prior studies of the U.S. R\&D tax credit have typically focused on larger firms, reflecting both data availability and the fact that smaller firms with no tax liability received limited benefits. In our sample of small Canadian firms, over half of the firm-year observations had no tax liability, and would therefore only receive carry-forwards under U.S. policy prior to 2016 as opposed to cash under SRED. We show that Canada's SRED program is particularly effective at stimulating $R \& D$ for these small zero-taxliability firms. Evaluating the impacts of recent changes in the U.S. R\&D tax credit is a promising topic for future research, particularly if it becomes possible to link policy-induced changes in $R \& D$ spending to innovation outcomes for a broader range of public and privately owned firms. 


\section{REFERENCES}

Akcigit, U. and W. Kerr (2010). Growth Through Heterogeneous Innovations. NBER Working Paper, \#16443.

Altshuler, R. (1988). A dynamic analysis of the research and experimentation credit. National Tax Journal 41, 453-466.

Auten, G. and R. Caroll (1999). The Effect of Income Taxes on Household Income. Review of Economics and Statistics 81(4), 681-693.

Baghana, R. and P. Mohnen (2009). Effectiveness of R\&D tax incentives in small and large enterprises in Quebec. Small Business Economics 33, 91-107.

Bailey, M. N. and R. Lawrence (1992). Tax Incentives for R\&D: What Do the Data Tell Us? Technical report, Council on Research and Technology, Washington, DC.

Becker, B. (2015). Public R\&D Policies and Private R\&D Investment: A survey of the Empirical Evidence. Journal of Economic Surveys 29(5), 917-942.

Bernstein, J. I. and M. I. Nadiri (1988). Rates of Return on Physical and R\&D Capital and Structure of the Production Process: Cross Section and Time Series Evidence. NBER Working Paper \#2570.

Bloom, N., R. Griffith, and J. Van Reenen (2002). Do R\&D Tax Credits Work? Evidence from a Panel of Countries, 1979-1997. Journal of Public Economics 85, 1-31.

Blundell, R., R. Grifith, and F. Windmeijer (2002). Individual effects and dynamics in count data models. Journal of Econometrics 108, 113-121.

Chen, Z., Zhikuo, L. J. C. S. Serrato, and D. Xu (2017). Notching R\&D Investment with Corporate Income Tax Cuts in China. Working Paper.

Cohen, W. and S. Klepper (1996). Firm Size and the Nature of Innovation within Industries: The Case of Process and Product R\&D. The Review of Economics and Statistics 78(2), 232-243.

Congressional Budget Office (2007). Federal support for research and development. Publication \#2927.

Czarnitzki, D., P. Hanel, and J. M. Rosa (2011). Research Policy 40, 217-229.

Dagenais, M., P. Mohnen, and P. Therrien (1997). Do Canadian Firms Respond to Fiscal Incentives to Research and Development? Technical report, CIRANO, Discussion Paper 97s-34.

Dechezleprêtre, A., E. E. R. Martin, K.-T. Nguyen, and J. V. Reenen (2016). Do Tax Incentives for Research Increase Firm Innovation? An RD Design for R\&D. CEP Discussion Paper 1413. 
Garicano, L., C. Lelarge, and J. Van Reenen (2016). Firm size distortions and the productivity distribution: Evidence from france. American Economic Review forthcoming.

Gruber, J. and E. Saez (2002). The Elasticity of Taxable Income: Evidence and Implications. Journal of Public Economics 84, 1-32.

Guceri, I. and L. Liu (2015). Effectiveness of fiscal incentives for R\&D: a quasi-experiment. Oxford University for Business Taxation Working Paper 15/12.

Hall, B. H. (1993). R\&D Tax Policy During the Eighties: Success or Failure? Tax Policy and the Economy 7, 1-36.

Hall, B. H., Z. Griliches, and J. A. Hausman (1986). Patents and R\&D: Is There a Lag? International Economic Review 27(2), 265-283.

Hall, B. H. and J. Van Reenen (2000). How Effective Are Fiscal Incentives for R\&D? A Review of the Evidence. Research Policy 29, 449-469.

Hao, K. Y. and A. Jaffe (1993). Effect of Liquidity on Firm's R\&D Spending. Economics of Innovation and New Technology 2, 275-282.

Harhoff, D. (1997). Are there Financing Constraints for R\&D and Investment in German Manufacturing Firms? ENSAE Annales d'Economie et de Statistique 49-50, 421-456.

Himmelberg, C. P. and B. C. Petersen (1994). R\&D and Internal Finance: A Panel Study of Small Firms in High-Tech Industries. The Review of Economics and Statistics 76(1), 38-51.

J. M. C. Santos-Silva and S. Tenreyro (2006). The Log of Gravity. Review of Economics and Statistics 88, $641-658$.

Jorgenson, D. (1963). Capital theory and investment behavior. American Economic Review 53(2), $247-259$.

Koga, T. (2003). Firm size and R\&D tax incentives. Technovation 23(7), 643-648.

Lach, S. and M. Schankerman (1989). Dynamics of R\&D and Investment in the Scientific Sector. Journal of Politial Economy 97(4), 880-904.

Lokshin, B. and P. Mohnen (2012). How effective are level-based R\&D tax credits? Evidence from the Netherlands. Applied Economics 44(12), 1527-1538.

Mansfield, E. (1986). The R\&D Tax Credit and Other Technology Policy Issues. American Economic Review 76, 190-194.

Rao, N. (2016). Do Tax Credits Stimulate R\&D Spending? The Effect of the R\&D Tax Credit in its First Decade. Journal of Public Economics 140, 1-12. 
Swenson, C. (1992). Some tests of the incentive effects of the research and experimentation tax credit. Journal of Public Economics 49, 203-218.

Tyson, L. and G. Linden (2012). The Corporate R\&D Tax Credit and U.S. Innovation and Competitiveness. Technical report.

Wilson, D. J. (2009). Beggar Thy Neighbor? The In-State, Out-of-State, and Aggregate Effects of R\&D Tax Credits. Review of Economics and Statistics 91 (2), 431-426.

Windmeijer, F. (2000). Moment Conditions for Fixed Effects Count Data Models with Endogenous Regressors. Economics Letters 68, 21-24.

Yohei, K. (2011). Effect of R\&D Tax Credits for Small and Medium-sized Enterprises in Japan: Evidence from Firm-Level Data. RIETI Discussion Paper Series 11-E-066.

Zwick, E. and J. Mahon (2014). Do Financial Frictions Amplify Fiscal Policy? Evidence from Business Investment Stimulus. Working Paper Harvard University. 


\section{Appendix A - ONLINE PUBLICATION ONLY}

This appendix provides evidence of "bunching" in R\&D investment at the expenditure limit, and proposes a simple model along the lines of Garicano et al. (2016) to rationalize this behavior. We begin by showing that when firms cross the expenditure limit threshold, they respond to the increased marginal cost of R\&D.

Figure A-1 is divided into six panels, with the top row corresponding to data from the pre-policy time period, and the bottom row using data from after the policy change. Each graph shows a count (or probability density) of firm-year observations conditional on distance from the expenditure limit, which is indicated by a vertical line. The dots are actual frequencies (i.e., the number of firmyear observations where $R \& D$ expenditure is at a certain level relative to the threshold). The lines correspond to fitted values and a 95 percent confidence interval from a quadratic model with a break-point at the expenditure limit. ${ }^{27}$

The first column in Figure A-1 shows that for "Control" firms with lagged taxable income below $\$ 200$ thousand, there is a large jump in the probability density right at the expenditure limit. This jump in probability mass above the EL threshold suggests that the size of the marginal R\&D investment falls when the after-tax marginal cost of $\mathrm{R} \& \mathrm{D}$ increases, making firm-year observations less "spread out" along the X-axis.

The middle column examines firm-year observations in the "Treatment" group relative to the pre-policy expenditure limit. Comparing these graphs to the lefthand column, it appears that firms in the "Treatment" sample are less sensitive to the expenditure limit. However, there is a notable increase in the frequency (density) of observations as we move from the pre to the post-policy time-period

\footnotetext{
${ }^{27}$ To produce each panel in Figure A-1, we first created a variable $X_{i t}$, equal to firm $i$ 's Total RES in year $t$ minus the relevant expenditure limit $E L_{i t}$. Next, using observations where $\left|X_{i t}\right|<\$ 1$ million, we counted the number of firm-years where $X_{i t}$ fell into each of a series of 80 "bins" with a bandwidth of $\$ 25,000$. Formally, letting $k=-39 \ldots 40$ index the bins, we created variables $Y_{k}=\sum_{i, t} 1[25,000 *$ $\left.\left.(k-1)<X_{i t} \leq 25,000 * k\right)\right]$ and $X_{k}=25 k$. We then created scatter plots of the 80 values of $(Y, X)$, along with fitted values and $95 \%$ confidence intervals from the regression: $Y=\alpha+\beta_{1} X+\beta_{2} X^{2}+1[X>$ $0]\left\{\alpha_{2}+\gamma_{1} X+\gamma_{2} X^{2}\right\}+\varepsilon_{k}$.
} 
Figure A-1. Bunching at the Expenditure Limit

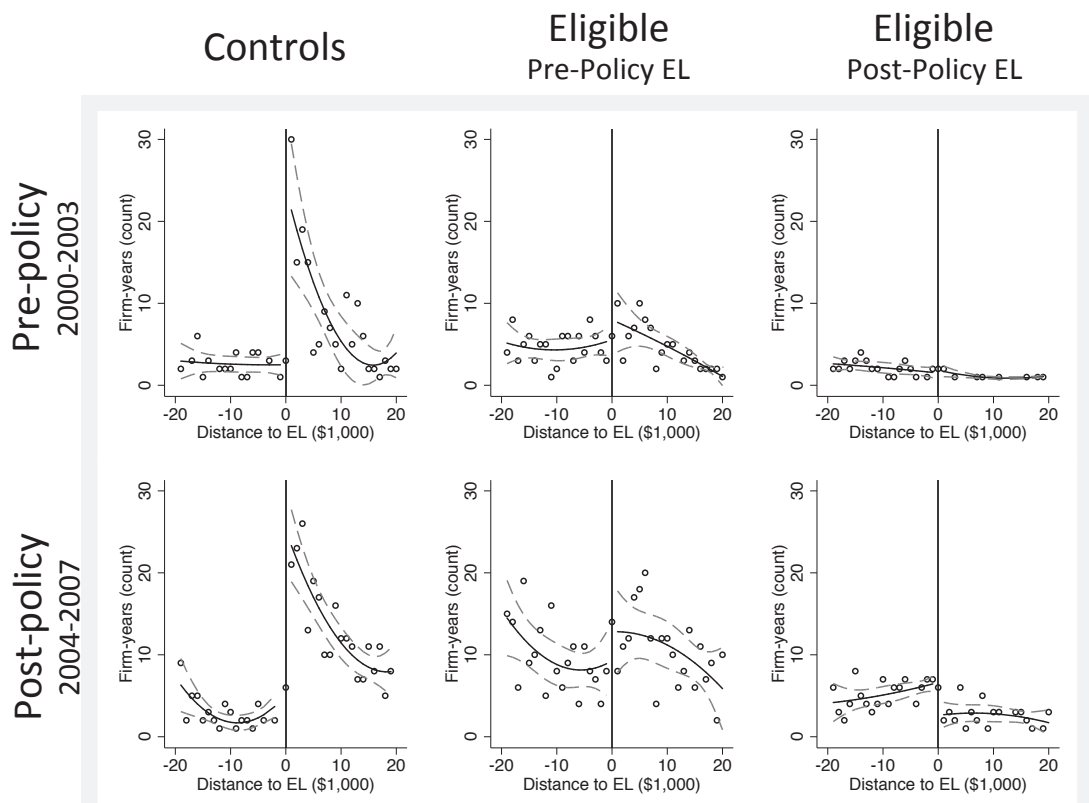

(i.e. from the top to the bottom row) in the middle column. This shows that firms are more willing to spend at or above the pre-policy expenditure limit after that limit has been increased. This is the source of variation used to identify the main results in the body of the paper.

Finally, the right-hand column in Figure A-1 shows the probability density in a neighborhood of the post-policy expenditure limit. In the top-right cell, we can see that there are very few firm-year observations from the pre-policy period that spend enough on $R \& D$ to reach the post-policy threshold. However, in the bottom-right cell, we can observe not only more observations, but also a discontinuous drop in the density at the expenditure limit. We interpret this bunching as evidence that firms are aware of the change in the SRED policy, and are adjusting their spending to take advantage of the higher threshold.

Because the bunching of Control observations just above the expenditure limit in the left-most column of Figure A-1 may seem counter-intuitive, we now provide 
a simple model to illustrate the the incentives behind this behavior. The model rests on two assumptions: (1) firms differ in their marginal productivity of R\&D, and (2) there is a sharp increase in the marginal cost of $R \& D$ at the expenditure limit.

Suppose that a firm investing $x$ in $\mathrm{R} \& \mathrm{D}$ receives gross benefits $B(x ; \eta)=\eta x^{\theta}$, where $\theta<1$ and $\eta$ is a random parameter with cumulative distribution $F$ (Assumption 1). Further, suppose that the marginal cost of $\mathrm{R} \& \mathrm{D}$ is $c^{L}$ up to some expenditure limit $E L$, and $c^{H}$ thereafter (Assumption 2), so total costs are $C(x)=c^{L} \min \{x, E L\}+c^{H} \max \{0, x-E L\}$. The first-order condition for R\&D investment then implies that:

$$
x^{*}(\eta)= \begin{cases}{\left[\frac{\theta \eta}{c}\right]^{1 /(1-\theta)}} & \text { if } \eta \leq \underline{\eta} \text { or } \eta \geq \bar{\eta} \\ E L & \text { if } \underline{\eta}<\eta<\bar{\eta},\end{cases}
$$

where $\underline{\eta}=c^{L} \frac{E L^{(1-\theta)}}{\theta}$, and $\bar{\eta}=c^{H} \frac{E L^{(1-\theta)}}{\theta}$. Thus, Assumptions 1 and 2 suffice to generate a mass point in the distribution of $x$ at the expenditure limit, since there is an atom of types $[\underline{\eta}, \bar{\eta}]$ that spend exactly $x^{*}=E L$.

Now let $g(x)$ denote the density of $x$. Applying the chain rule, we have $g(x)=$ $F^{\prime}(\eta(x)) \eta^{\prime}(x)$, where $\eta(x)$ is the inverse of the optimal R\&D investment implied by the first-order condition (A-1). Taking the limits of $g(x)$ from above and below as $x$ approaches $E L$, we have

$$
\lim _{x \uparrow E L}=F^{\prime}(\underline{\eta}) c^{L} \frac{(1-\theta)}{\theta E L^{\theta}} \text { and } \lim _{x \downarrow E L}=F^{\prime}(\bar{\eta}) c^{H} \frac{(1-\theta)}{\theta E L^{\theta}}
$$

Thus, a graph of $g(x)$ will have a discontinuous increase at $x=E L$ if and only if $c^{H} F^{\prime}(\bar{\eta})>c^{L} F^{\prime}(\underline{\eta})$. That is what we observe in the lefthand column of Figure A-1, for firm-years in the Control sample (i.e. with lagged taxable income below $\$ 200$ thousand). Intuitively, we see bunching above the cutoff because the increase in marginal cost leads more firms to "drop out" for each additional 
dollar of R\&D investment, and this produces an increase in the density $g(x)$ at the expenditure limit.

Although Figure A-1 provides strong evidence that firms respond to the R\&D tax credit, we do not use this variation in our empirical analysis for two reasons. First, the marginal cost of $\mathrm{R} \& \mathrm{D}$ is endogenous - our main outcome variable appears on the x-axis in Figure A-1. ${ }^{28}$ And second, only about two percent of the firm-year observations in our data set actually cross the expenditure limit threshold.

${ }^{28}$ This simultaneity also prevents us from using a regression discontinuity design to estimate the impact of tax credits at the expenditure limit. 


\section{Appendix B - ONLINE PUBLICATION ONLY}

Table B-1-Canadian-Controlled Private Corporation Marginal Tax Rates

\begin{tabular}{lcccccccc}
\hline & 2000 & 2001 & 2002 & 2003 & 2004 & 2005 & 2006 & 2007 \\
\hline $\begin{array}{l}\text { Maximum small business } \\
\text { limit (\$thous.) }\end{array}$ & $\$ 200$ & $\$ 200$ & $\$ 200$ & $\$ 225$ & $\$ 250$ & $\$ 300$ & $\$ 300$ & $\$ 400$ \\
$\begin{array}{l}\text { Tax rate up to reduced } \\
\text { business limit }\end{array}$ & 13.12 & 13.12 & 13.12 & 13.12 & 13.12 & 13.12 & 13.12 & 13.12 \\
$\begin{array}{l}\text { Tax rate from reduced } \\
\text { business limit to } \$ 300 \mathrm{~K}\end{array}$ & 29.12 & 22.12 & 22.12 & 22.12 & 22.12 & 22.12 & 22.12 & 22.12 \\
$\begin{array}{l}\text { Tax rate above } \$ 300 \mathrm{~K} \text { or small- } \\
\text { business deduction threshold }\end{array}$ & 29.12 & 28.12 & 26.15 & 24.12 & 22.12 & 22.12 & 22.12 & 22.12 \\
\hline
\end{tabular}

${ }^{\dagger}$ The reduced business limit varies between $\$ 0$ and the maximum small business deduction threshold depending on the firm's size as determined by taxable capital employed in Canada. 
TABle B-2-Impacts of SRED for Balanced Panel

\begin{tabular}{|c|c|c|c|c|c|c|}
\hline \multicolumn{7}{|c|}{$\begin{array}{c}\text { Specification: Poisson QML Regression } \\
\text { Unit of Analysis: Firm-Year }\end{array}$} \\
\hline Outcome Variable & $\begin{array}{l}\text { Total } \\
\mathrm{R} \& \mathrm{D} \\
(1)\end{array}$ & $\begin{array}{l}\text { Total } \\
\text { R\&D } \\
(2)\end{array}$ & $\begin{array}{l}\text { Total } \\
\text { R\&D } \\
(3)\end{array}$ & $\begin{array}{l}\mathrm{R} \& \mathrm{D} \\
\text { Wages } \\
(4)\end{array}$ & $\begin{array}{l}\text { R\&D } \\
\text { Contracts } \\
(5)\end{array}$ & $\begin{array}{l}\text { Non-R\&D } \\
\text { Investment } \\
\quad(6)\end{array}$ \\
\hline Eligible X Post policy & $\begin{array}{c}0.15 \\
(0.06)\end{array}$ & $\begin{array}{c}0.18 \\
(0.05)\end{array}$ & $\begin{array}{c}0.14 \\
(0.05)\end{array}$ & $\begin{array}{c}0.12 \\
(0.05)\end{array}$ & $\begin{array}{c}0.23 \\
(0.10)\end{array}$ & $\begin{array}{c}0.11 \\
(0.10)\end{array}$ \\
\hline Eligible & $\begin{array}{c}0.11 \\
(0.04)\end{array}$ & $\begin{array}{c}0.07 \\
(0.04)\end{array}$ & $\begin{array}{c}0.03 \\
(0.04)\end{array}$ & $\begin{array}{c}0.01 \\
(0.04)\end{array}$ & $\begin{array}{c}0.09 \\
(0.09)\end{array}$ & $\begin{array}{c}0.12 \\
(0.08)\end{array}$ \\
\hline Post policy & $\begin{array}{c}0.15 \\
(0.03)\end{array}$ & & & & & \\
\hline $\begin{array}{l}\text { Firm FE } \\
\text { Year FE } \\
\text { Controls }\end{array}$ & $\begin{array}{l}\text { Yes } \\
\text { No } \\
\text { No }\end{array}$ & $\begin{array}{l}\text { Yes } \\
\text { Yes } \\
\text { No }\end{array}$ & $\begin{array}{l}\text { Yes } \\
\text { Yes } \\
\text { Yes }\end{array}$ & $\begin{array}{l}\text { Yes } \\
\text { Yes } \\
\text { Yes }\end{array}$ & $\begin{array}{l}\text { Yes } \\
\text { Yes } \\
\text { Yes }\end{array}$ & $\begin{array}{l}\text { Yes } \\
\text { Yes } \\
\text { Yes }\end{array}$ \\
\hline Psuedo-R2 & 0.75 & 0.75 & 0.80 & 0.84 & 0.68 & 0.58 \\
\hline Observations & 35,101 & 35,101 & 35,101 & 27,424 & 26,020 & 34,129 \\
\hline Number of firms & 4,495 & 4,495 & 4,495 & 3,515 & 3,326 & 4,364 \\
\hline Mean of outcome variable & 73,018 & 73,018 & 73,018 & 64,468 & 14,448 & 87,152 \\
\hline
\end{tabular}

Notes: Robust standard errors (clustered by firm) in parentheses. All models are estimated using a balanced panel of $\mathrm{N}=35,101$ firm-years; changes in sample size are due to omission of any firm with all-zero outcomes. The mean value of the outcome variable is calculated for all firm-years used in these estimations. 
Table B-3-Dropping Observations Above Expenditure Limit

\begin{tabular}{|c|c|c|c|c|}
\hline \multicolumn{5}{|c|}{$\begin{array}{l}\text { Specification: Poisson QML Regression } \\
\text { Unit of Analysis: Firm-Year }\end{array}$} \\
\hline Outcome Variable & $\begin{array}{l}\text { Total } \\
\text { R\&D } \\
(1)\end{array}$ & $\begin{array}{l}\text { Total } \\
\text { R\&D } \\
(2)\end{array}$ & $\begin{array}{l}\text { R\&D } \\
\text { Wages } \\
(3)\end{array}$ & $\begin{array}{l}\text { R\&D } \\
\text { Contracts } \\
(4)\end{array}$ \\
\hline Eligible X Post policy & $\begin{array}{c}0.13 \\
(0.05)\end{array}$ & $\begin{array}{c}0.12 \\
(0.04)\end{array}$ & $\begin{array}{c}0.07 \\
(0.04)\end{array}$ & $\begin{array}{c}0.29 \\
(0.10)\end{array}$ \\
\hline Eligible & $\begin{array}{c}0.11 \\
(0.04)\end{array}$ & $\begin{array}{c}0.04 \\
(0.03)\end{array}$ & $\begin{array}{c}0.05 \\
(0.03)\end{array}$ & $\begin{array}{c}0.06 \\
(0.08)\end{array}$ \\
\hline $\begin{array}{l}\text { Firm FE } \\
\text { Industry-Year FE } \\
\text { Controls }\end{array}$ & $\begin{array}{l}\text { Yes } \\
\text { Yes } \\
\text { No }\end{array}$ & $\begin{array}{l}\text { Yes } \\
\text { Yes } \\
\text { Yes }\end{array}$ & $\begin{array}{l}\text { Yes } \\
\text { Yes } \\
\text { Yes }\end{array}$ & $\begin{array}{l}\text { Yes } \\
\text { Yes } \\
\text { Yes }\end{array}$ \\
\hline Psuedo-R2 & 0.72 & 0.82 & 0.84 & 0.65 \\
\hline Observations & 47,579 & 47,579 & 37,711 & 35,299 \\
\hline Number of firms & 7,191 & 7,191 & 5,755 & 5,326 \\
\hline Mean of outcome variable & 72,360 & 72,360 & 61,050 & 16,993 \\
\hline
\end{tabular}

Notes: Robust standard errors (clustered by firm) in parentheses. The mean value of the outcome variable is calculated for all firmyears used in these estimations. 
Table B-4-Adjustment Cost Estimates for Balanced Panel

\begin{tabular}{|c|c|c|c|c|c|c|}
\hline \multirow{3}{*}{$\begin{array}{l}\text { Sample } \\
\text { R\&D Outcome Variable }\end{array}$} & \multicolumn{6}{|c|}{$\begin{array}{l}\text { Specification: Poisson QML Regression } \\
\text { Unit of Analysis: Firm-Year }\end{array}$} \\
\hline & \multicolumn{3}{|c|}{ All Firm-Years } & \multicolumn{3}{|c|}{ Non-NAICS 541 Firm-Years } \\
\hline & Total & Wages & Contracts & Total & Wages & Contracts \\
\hline Eligible X Policy X 541 & $\begin{array}{c}0.21 \\
(0.09)\end{array}$ & $\begin{array}{c}0.22 \\
(0.09)\end{array}$ & $\begin{array}{c}0.18 \\
(0.19)\end{array}$ & & & \\
\hline Eligible X NAICS 541 & $\begin{array}{l}-0.04 \\
(0.05)\end{array}$ & $\begin{array}{l}-0.06 \\
(0.04)\end{array}$ & $\begin{array}{l}-0.19 \\
(0.10)\end{array}$ & & & \\
\hline Policy X NAICS 541 & $\begin{array}{l}-0.07 \\
(0.08)\end{array}$ & $\begin{array}{l}-0.12 \\
(0.08)\end{array}$ & $\begin{array}{c}0.09 \\
(0.18)\end{array}$ & & & \\
\hline Eligible X Policy X Capital & & & & $\begin{array}{c}0.28 \\
(0.12)\end{array}$ & $\begin{array}{c}0.22 \\
(0.10)\end{array}$ & $\begin{array}{c}0.38 \\
(0.26)\end{array}$ \\
\hline Policy X Capital & & & & $\begin{array}{l}-0.27 \\
(0.07)\end{array}$ & $\begin{array}{l}-0.16 \\
(0.05)\end{array}$ & $\begin{array}{l}-0.34 \\
(0.13)\end{array}$ \\
\hline Eligible X Capital & & & & $\begin{array}{l}-0.16 \\
(0.09)\end{array}$ & $\begin{array}{l}-0.16 \\
(0.09)\end{array}$ & $\begin{array}{l}-0.09 \\
(0.20)\end{array}$ \\
\hline Eligible X Policy & $\begin{array}{c}0.07 \\
(0.06)\end{array}$ & $\begin{array}{c}0.04 \\
(0.05)\end{array}$ & $\begin{array}{c}0.15 \\
(0.13)\end{array}$ & $\begin{array}{l}-0.04 \\
(0.05)\end{array}$ & $\begin{array}{l}-0.04 \\
(0.06)\end{array}$ & $\begin{array}{c}0.03 \\
(0.17)\end{array}$ \\
\hline Eligible & $\begin{array}{c}0.05 \\
(0.04)\end{array}$ & $\begin{array}{c}0.05 \\
(0.04)\end{array}$ & $\begin{array}{c}0.06 \\
(0.10)\end{array}$ & $\begin{array}{c}0.11 \\
(0.04)\end{array}$ & $\begin{array}{c}0.11 \\
(0.05)\end{array}$ & $\begin{array}{c}0.09 \\
(0.13)\end{array}$ \\
\hline $\begin{array}{l}\text { Additional controls } \\
\text { Year Fixed Effects } \\
\text { Firm Fixed Effects }\end{array}$ & $\begin{array}{l}\text { Yes } \\
\text { Yes } \\
\text { Yes }\end{array}$ & $\begin{array}{l}\text { Yes } \\
\text { Yes } \\
\text { Yes }\end{array}$ & $\begin{array}{l}\text { Yes } \\
\text { Yes } \\
\text { Yes }\end{array}$ & $\begin{array}{l}\text { Yes } \\
\text { Yes } \\
\text { Yes }\end{array}$ & $\begin{array}{l}\text { Yes } \\
\text { Yes } \\
\text { Yes }\end{array}$ & $\begin{array}{l}\text { Yes } \\
\text { Yes } \\
\text { Yes }\end{array}$ \\
\hline Psuedo-R2 & 0.80 & 0.84 & 0.68 & 0.81 & 0.84 & 0.67 \\
\hline Observations & 35,101 & 27,424 & 26,020 & 26,251 & 19,273 & 19,945 \\
\hline Total Firms & 4,495 & 3,515 & 3,326 & 3,350 & 2,463 & 2,542 \\
\hline NAICS 541 / Capital Firms & 1,145 & 1,052 & 784 & 538 & 509 & 425 \\
\hline Mean of outcome & 73,018 & 64,468 & 14,448 & 61,821 & 56,343 & 10,600 \\
\hline
\end{tabular}


Table B-5-Samples Excluding Years Around SRED Policy-Change

\begin{tabular}{|c|c|c|c|c|c|}
\hline \multicolumn{6}{|c|}{$\begin{array}{c}\text { Specification: Poisson QML Regression } \\
\text { Unit of Analysis: Firm-Year } \\
\text { Outcome Variable: Total R\&D }\end{array}$} \\
\hline Sample & $\begin{array}{c}\text { Full } \\
\text { Sample } \\
(1)\end{array}$ & $\begin{array}{c}\text { Drop } \\
2003 \\
(2) \\
\end{array}$ & $\begin{array}{c}\text { Drop } \\
2004 \\
(3) \\
\end{array}$ & $\begin{array}{c}\text { Drop } \\
03-04 \\
(4) \\
\end{array}$ & $\begin{array}{c}\text { Drop } \\
03-05 \\
(5) \\
\end{array}$ \\
\hline Eligible X Post policy & $\begin{array}{c}0.18 \\
(0.04)\end{array}$ & $\begin{array}{c}0.19 \\
(0.05)\end{array}$ & $\begin{array}{c}0.22 \\
(0.05)\end{array}$ & $\begin{array}{c}0.22 \\
(0.06)\end{array}$ & $\begin{array}{c}0.22 \\
(0.06)\end{array}$ \\
\hline Eligible & $\begin{array}{c}0.00 \\
(0.03)\end{array}$ & $\begin{array}{l}-0.02 \\
(0.05)\end{array}$ & $\begin{array}{c}0.00 \\
(0.03)\end{array}$ & $\begin{array}{c}0.00 \\
(0.05)\end{array}$ & $\begin{array}{c}0.03 \\
(0.05)\end{array}$ \\
\hline $\begin{array}{l}\text { Firm FE } \\
\text { Year FE } \\
\text { Controls }\end{array}$ & $\begin{array}{l}\text { Yes } \\
\text { Yes } \\
\text { Yes }\end{array}$ & $\begin{array}{l}\text { Yes } \\
\text { Yes } \\
\text { Yes }\end{array}$ & $\begin{array}{l}\text { Yes } \\
\text { Yes } \\
\text { Yes }\end{array}$ & $\begin{array}{l}\text { Yes } \\
\text { Yes } \\
\text { Yes }\end{array}$ & $\begin{array}{l}\text { Yes } \\
\text { Yes } \\
\text { Yes }\end{array}$ \\
\hline Observations & 48,638 & 40,185 & 41,906 & 32,487 & 25,437 \\
\hline Number of firms & 7,239 & 6,850 & 7,170 & 6,486 & 6,116 \\
\hline
\end{tabular}

TABle B-6-OLS SPecification for SRED Policy ImpaCt

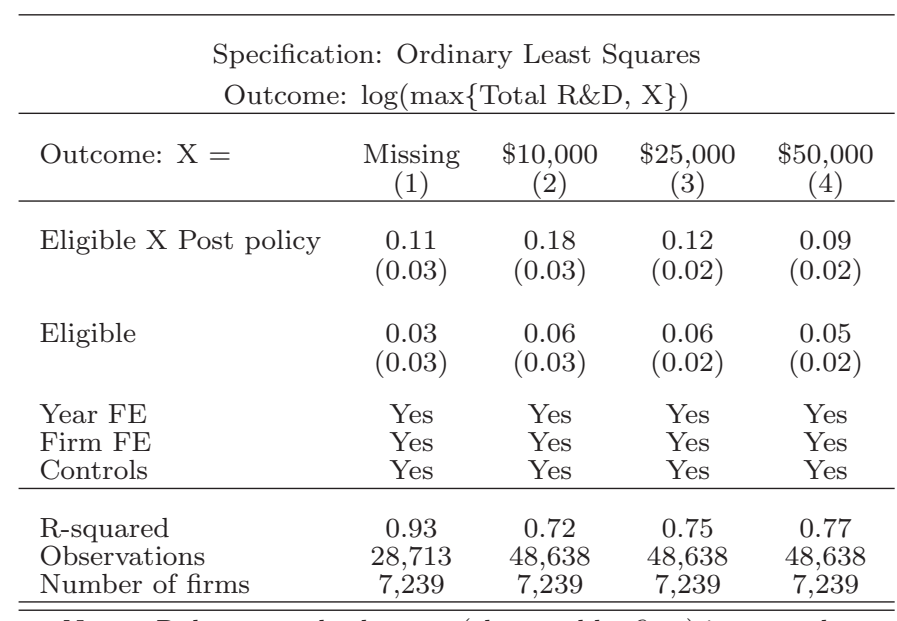

Notes: Robust standard errors (clustered by firm) in parentheses.

All models are estimated using an unbalanced panel of all available firm-years. Model (1) drops observations with no reported $\mathrm{R} \& \mathrm{D}$ expenditures. 
Table B-7-Alternative Measure of Tax-Liability (No Current Revenue)

\begin{tabular}{lccc}
\hline \multicolumn{4}{c}{ Specification: Poisson QML Regression } \\
Unit of Analysis: Firm-Year \\
R\&D Outcome Variable & Total & Wages & Contracts \\
& $(1)$ & $(2)$ & $(3)$ \\
\hline Eligible X Policy X Zero-tax & 0.28 & 0.19 & 0.51 \\
& $(0.10)$ & $(0.10)$ & $(0.24)$ \\
Eligible X Zero-tax & -0.28 & -0.18 & -0.44 \\
& $(0.04)$ & $(0.04)$ & $(0.08)$ \\
Policy X Zero-tax & -0.15 & -0.13 & -0.24 \\
& $(0.08)$ & $(0.08)$ & $(0.17)$ \\
Eligible X Policy & 0.02 & 0.03 & 0.07 \\
Eligible & $(0.04)$ & $(0.04)$ & $(0.11)$ \\
Zero-tax-liability & 0.08 & 0.06 & 0.15 \\
& $(0.03)$ & $(0.03)$ & $(0.09)$ \\
Additional controls & 0.11 & 0.07 & 0.11 \\
Year Fixed Effects & $(0.03)$ & $(0.03)$ & $(0.06)$ \\
Firm Fixed Effects & Yes & Yes & Yes \\
\hline Psuedo-R2 & Yes & Yes & Yes \\
Observations & Yes & Yes & Yes \\
Total Firms & 0.81 & 0.83 & 0.67 \\
Mean of outcome & 48,638 & 38,748 & 36,235 \\
\hline \hline
\end{tabular}

Notes: Robust standard errors (clustered by firm) in parentheses. All models are estimated using an unbalanced panel of all available firm-years; changes in sample size occur when firms with all-zero outcomes are dropped from the conditional fixed-effects specification. The mean value of the outcome variable is calculated for all firm-years used in the estimation. 
Table B-8-Means and Sample Sizes for Table 5

\begin{tabular}{|c|c|c|c|}
\hline & $\begin{array}{c}\text { All } \\
\text { Firms }\end{array}$ & $\begin{array}{l}\text { Taxes } \\
\text { Owed }\end{array}$ & $\begin{array}{l}\text { Zero Tax } \\
\text { Liability }\end{array}$ \\
\hline \multicolumn{4}{|c|}{ Pre-2004 Mean Outcome } \\
\hline Total R\&D & 161,291 & 124,785 & 322,983 \\
\hline R\&D Wages & 106,075 & 87,294 & 189,734 \\
\hline R\&D Contracts & 26,403 & 20,407 & 53,003 \\
\hline \multicolumn{4}{|c|}{ Post-2003 Eligible Observations } \\
\hline Observations & 2,346 & 1,975 & 371 \\
\hline
\end{tabular}

